\title{
Spatial and Temporal Variation in Fine Particulate Matter Mass and Chemical Composition: The Middle East Consortium for Aerosol Research Study
}

\author{
Ziad Abdeen, ${ }^{1}$ Radwan Qasrawi, ${ }^{1}$ Jongbae Heo, ${ }^{2}$ Bo Wu, ${ }^{2,3}$ Jacob Shpund, \\ Arye Vanger, ${ }^{4}$ Geula Sharf, ${ }^{4}$ Tamar Moise, ${ }^{5}$ Shmuel Brenner, ${ }^{5}$ Khaled Nassar, ${ }^{6}$ Rami Saleh, ${ }^{6}$

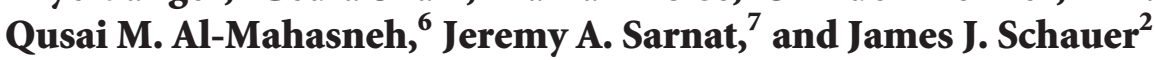 \\ ${ }^{1}$ Al Quads University (AQU), Beit Hanina, P.O. Box 51000, Jerusalem, Palestine \\ ${ }^{2}$ Environmental Chemistry and Technology Program, University of Wisconsin-Madison, Madison, \\ WI 53706, USA \\ ${ }^{3}$ Institute of Applied Ecology, Chinese Academy of Sciences, Shenyang 110016, China \\ ${ }^{4}$ Israel Union for Environment Defense (IUED), 65134 Tel Aviv, Israel \\ ${ }^{5}$ Arava Institute for Environmental Studies (AIES), 88840 Hevel Eilot, Israel \\ ${ }^{6}$ Jordan Society for Sustainable Development (JSSD), Amman 840251, Jordan \\ ${ }^{7}$ Department of Environmental Health, Emory University, Atlanta, GA 30322, USA
}

Correspondence should be addressed to Ziad Abdeen; zabdeen13@gmail.com

Received 21 January 2014; Accepted 24 May 2014; Published 18 June 2014

Academic Editor: Andrew Hursthouse

Copyright (c) 2014 Ziad Abdeen et al. This is an open access article distributed under the Creative Commons Attribution License, which permits unrestricted use, distribution, and reproduction in any medium, provided the original work is properly cited.

Ambient fine particulate matter $\left(\mathrm{PM}_{2.5}\right)$ samples were collected from January to December 2007 to investigate the sources and chemical speciation in Palestine, Jordan, and Israel. The 24-h $\mathrm{PM}_{2.5}$ samples were collected on 6-day intervals at eleven urban and rural sites simultaneously. Major chemical components including metals, ions, and organic and elemental carbon were analyzed. The mass concentrations of $\mathrm{PM}_{2.5}$ across the 11 sites varied from 20.6 to $40.3 \mu \mathrm{g} / \mathrm{m}^{3}$, with an average of $28.7 \mu \mathrm{g} / \mathrm{m}^{3}$. Seasonal variation of $\mathrm{PM}_{2.5}$ concentrations was substantial, with higher average concentrations $\left(37.3 \mu \mathrm{g} / \mathrm{m}^{3}\right)$ in the summer (April-June) months compared to winter (October-December) months $\left(26.0 \mu \mathrm{g} / \mathrm{m}^{3}\right)$ due mainly to high contributions of sulfate and crustal components. $\mathrm{PM}_{2.5}$ concentrations in the spring were greatly impacted by regional dust storms. Carbonaceous mass was the most abundant component, contributing $40 \%$ to the total $\mathrm{PM}_{2.5}$ mass averaged across the eleven sites. Crustal components averaged $19.1 \%$ of the $\mathrm{PM}_{2.5}$ mass and sulfate, ammonium, and nitrate accounted for $16.2 \%, 6.4 \%$, and 3.7\%, respectively, of the total $\mathrm{PM}_{2.5}$ mass. The results of this study demonstrate the need to better protect the health and welfare of the residents on both sides of the Jordan River in the Middle East.

\section{Introduction}

Atmospheric particulate matter (PM) is a complex, heterogeneous mixture, whose physical size distribution and chemical composition change in time and space, and is dependent on various emissions sources, atmospheric chemistry, and meteorological conditions [1,2]. Atmospheric PM has important health and environmental impacts including (a) longrange transport of toxic materials; (b) visibility degradation; (c) hydrologic cycle combined with global climate change; and (d) radiation balance of the Earth [1-3]. There have been hundreds of epidemiologic and toxicologic studies that have shown associations between PM, specifically emitted by major mobile and stationary combustion sources, and excess morbidity and mortality due mainly to respiratory and cardiovascular disease [4-6].

The vast majority of these studies examining air pollution exposures and health have been conducted in the US and Western Europe, where standards for emissions and ambient air quality have been largely successful in reducing average 
outdoor pollution levels [7, 8]. Regulation of air pollution in the Middle East region is, at best, in its initial stages, with air quality standards for gaseous pollutants typically higher than those measured in Europe and North America [9-15].

Previous limited monitoring studies throughout the Middle East have indicated that PM mass concentrations are elevated throughout this region $[14,16,17]$. Information about PM composition, a likely factor associated with its toxicity, is virtually nonexistent. To our knowledge, no studies have been conducted, regionally, throughout the Middle East examining both levels and spatiotemporal trends of fine particulate matter $\left(\mathrm{PM}_{2.5}\right)$ components. A greater understanding of $\mathrm{PM}_{2.5}$ composition, from a broader regional perspective, is of substantial interest for several reasons. First, because ongoing research is providing evidence that different components of $\mathrm{PM}_{2.5}$ have different risk factors [18], effective control strategies aimed at protecting public health need to be directed at those components that pose the greatest risk. Second, this information provides the foundation to develop effective control strategies, since the various components are related to different emission sources. Third, air quality regulations have largely focused on local or national control strategies but it is likely that emissions from countries that share the same airshed, such as Palestine, Israel, and Jordan, impact each other and that regional multinational air quality control strategies will need to be developed to best protect human health.

This current analysis provides results on $\mathrm{PM}_{2.5}$ concentrations and chemical composition collected as part of a novel monitoring study conducted over a relatively large geographical area within the Middle East (Palestine, Jordan, and Israel). The Middle East Consortium for Aerosol Research Study (MECARS) examines PM levels and seasonal variation for a range of chemical components, including water-soluble ions, carbonaceous species, and inorganic elements, and compares ambient concentrations of these components among adjacent sites which are separated by political boundaries (e.g., EilatIsrael and Aqaba-Jordan) in an effort to better understand the sources of these chemical components. Although a number of studies have examined the spatiotemporal evaluation and characteristics of $\mathrm{PM}_{2.5}$ chemical components and sources within an airshed, there are still uncertainties in addressing the spatial variability. Therefore, the results from this study can provide better understanding of the spatial differences of sources and chemical components of $\mathrm{PM}_{2.5}$ in different geographic regions and also be used to make more effective regulatory policies.

\section{Measurement}

2.1. Sampling Sites. PM samples were collected at eleven ambient air quality monitoring stations in Palestine (Nablus, East Jerusalem, and Hebron), Jordan (Amman, Aqaba, Rahma, and Zarka), and Israel (West Jerusalem, Eilat, Tel Aviv, and Haifa). The locations of the eleven stations are shown in Figure 1. Collectively, these stations were established as part of MECARS in 2007. These ambient monitoring stations were situated in populated areas, with the exception of the Rahma desert site and were intended to provide information pertaining to population exposure to PM. Special emphasis was placed on a comparison among different monitoring sites located in a single airshed. For example, West Jerusalem and East Jerusalem are part of the same urban area, and while Nablus and Hebron are only located $\sim 50 \mathrm{~km}$ from each other, different in lifestyle, economic activity, vehicle fleet composition, and socioeconomic indicators may influence the outdoor $\mathrm{PM}_{2.5}$ concentrations and composition in each location. The two adjacent cities of Aqaba and Eilat differ greatly in size, economic character, building conditions, and lifestyle and are effectively isolated from each other at ground level by the international border. Concurrent monitoring of ambient $\mathrm{PM}_{2.5}$ was expected to elucidate differences among exposures in adjacent cities and reveal the causes of these differences. The sampling sites and associated economic and social differences across the sites have been more detailed in Sarnat et al. [19].

All of the monitoring sites were selected to minimize potential impacts from localized sources and activities. Sites were located in large clearings on relatively high ground and were situated a reasonable distance from busy thoroughfares and pollutant industrial point sources. The PM sampling stations used by the MECARS were situated on the roofs of buildings, resulting in an effective inlet height between 14 and $20 \mathrm{~m}$ above the ground. Therefore, the sampling stations were representative of urban background levels of PM concentrations for each site [20].

2.2. Sample Collection and Analysis. $\mathrm{PM}_{2.5}$ samples were collected every 6th day during 2007 (62 sampling events at each site), effectively once per week on alternating days of the week, to provide weekday and weekend measurements. Multichannel air samplers, designed and built specifically for this project by URG Corp (Chapel Hill, NC, USA), were comprised of two $\mathrm{PM}_{2.5}$ sampling trains, each of which operated at a total flow rate of 16.7 liters per minute (LPM). Each sampling train consisted of a sample inlet, a $\mathrm{PM}_{2.5}$ cyclone, a flow splitter, and two 8.35 LPM sample legs. All components of the sampler that were exposed to the aerosol sample flow were fabricated from Teflon-coated aluminum or Teflon-coated stainless steel. One sample train contained two filter holders used to collect particulate matter on $47 \mathrm{~mm}$ Teflon membrane filters for mass determination and analysis of inorganic particulate matter components. The second sampler leg contained one $47 \mathrm{~mm}$ quartz fiber filter (QFF) that collected particulate matter used for analysis of organic carbon (OC) and elemental carbon (EC) as well as individual organic compounds. The 4 th sampling leg was replaced with a spacer to maintain standard flow rates and standard sampler construction and was not used for sampling. Air sampling flow rates on the sampler were controlled with critical orifices and the samplers were started at midnight on each sampling day and shut off after 24 hours using electronically controlled timers. Flow rates were measured with calibrated rotameters before and after sampling. Monthly field and lab blanks were analyzed for quality control and quality assurance and to blank corrections. The sampling system can be found in the supporting information (see Figure S1 in Supplementary Material available online at 

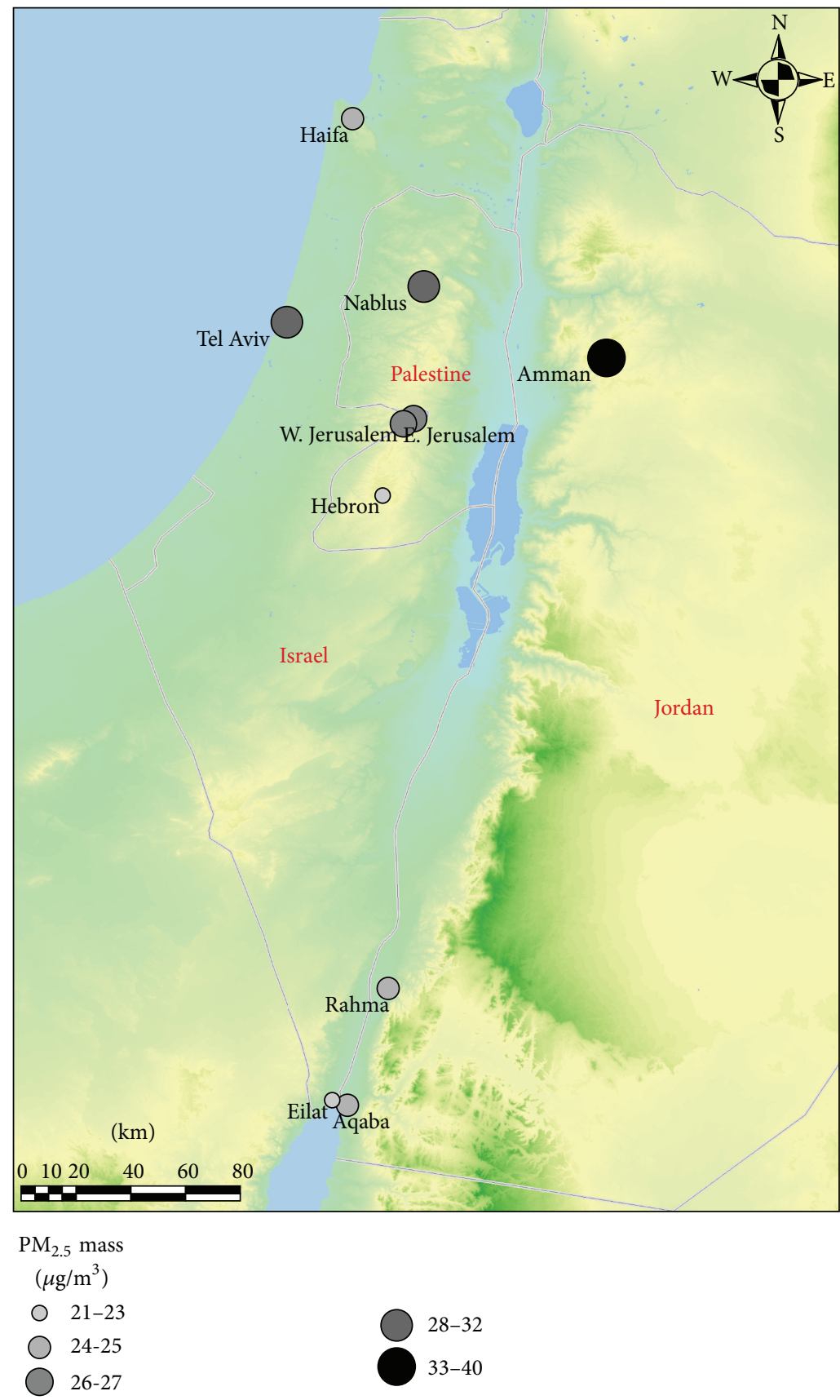

FIGURE 1: Sample site locations and their annual average $\mathrm{PM}_{2.5}$ mass concentrations.

http://dx.doi.org/10.1155/2014/878704) and additional information on the collecting system has been previously published in von Schneidemesser et al. [21] and Sarnat et al. [19].

Prior to sample collection the QFFs were baked at $550^{\circ} \mathrm{C}$ for a minimum of 16 hours to remove residual carbonaceous material. Before and after sample collection, the QFFs were stored in prebaked aluminum foil in plastic Petri dishes sealed with Teflon tape. Each sample collected on the quartz fiber filter was analyzed for elemental and organic carbon (ECOC) by thermal-optical analysis (Sunset Laboratory, Inc., Forest Grove, OR) using the ACE-Asia method [22].
The Teflon filters were used to collect and measure $\mathrm{PM}_{2.5}$ mass, gravimetrically. Water-soluble ions and major and trace elements concentrations were determined by analyzing the collected $\mathrm{PM}_{2.5}$ mass using ion chromatography [23] and by $\mathrm{X}$-ray fluorescence (XRF), respectively. The XRF analysis was conducted at the Desert Research Institute (DRI) in Reno, Nevada, using the EPA Compendium Method 10-3.3 [24]. The samples were stored frozen at all times after sampling and before chemical analysis except during shipping where they were kept cold to avoid volatility losses and chemical transformation. Explicit details of the filter samples handling 
and storage have been found in previously published works $[25,26]$. QA/QC was performed to trace any contamination due to sample handling, with 12 sets of field blanks (one per sampling month) for each site. The blank filters were handled in the same manners as other 24-hour samples. All measurements were blank subtracted using the results of analyses of the blank filters. The field blank values for $\mathrm{PM}_{2.5}$ mass were not statistically different from zero. A mean of blank values for other chemical constituents varied, and the results can be found in Table S1. Meteorological data (temperature, air pressure, humidity, solar radiation, wind speed, and wind direction) were collected from locally equipped monitoring stations. In the Middle East areas, the weather changes from season to season, showing that from May to October is summer with hot and dry weather, from December to January is the coldest weather with high precipitation, and spring is short and lasts a little less than a month around April. For the present paper, calendar quarters $(\mathrm{Q} 1$ = January-March; Q2 = April-June; Q3 = July-September; Q4 = October-December) were used to estimate monthly trends in $\mathrm{PM}_{2.5}$ mass and chemical compounds.

\section{Result and Discussion}

3.1. $\mathrm{PM}_{2.5}$ Mass Concentrations. The average $\mathrm{PM}_{2.5}$ mass concentrations across the 11 sites ranged between 20.6 and $40.3 \mu \mathrm{g} / \mathrm{m}^{3}$, with an overall average of $28.7 \mu \mathrm{g} / \mathrm{m}^{3}$. These differences were expected based on the diverse site locations (Figure 1) and different local pollution sources. In these areas the key primary PM sources are energy production, industrial activities, and vehicular emissions, as well as dust [27].

Data analysis for Q4 and Q2 months indicated higher total $\mathrm{PM}_{2.5}$ concentrations during the warmer months of the year. In the Q2, an average across-site concentration of $37.3 \mu \mathrm{g} / \mathrm{m}^{3}$ was measured, with a range of $12.2 \mu \mathrm{g} / \mathrm{m}^{3}$ to $133 \mu \mathrm{g} / \mathrm{m}^{3}$. The Q4 values averaged $20.2 \mu \mathrm{g} / \mathrm{m}^{3}$, with a range of $5.7 \mu \mathrm{g} / \mathrm{m}^{3}$ to $66.6 \mu \mathrm{g} / \mathrm{m}^{3}$. The relative high concentrations in the warmer months were mainly driven by the synoptic wind conditions (i.e., the Red Sea Trough and Saharan Cyclone), which lead to elevated dust concentrations that occur in April-May in the region [19]. Among the sites, annual concentrations were highest in Amman, with an average concentration of $40.3 \mu \mathrm{g} / \mathrm{m}^{3}$ and a maximum concentration of $162.0 \mu \mathrm{g} / \mathrm{m}^{3}$. This high annual concentration is likely attributable to local anthropogenic emissions (industrial emissions and heavy vehicular traffic) of particulate matter compared to the other sites. During this study period, lead gasoline was used in Jordan, but not used in Israel, and traffic volumes were higher than other sites in Jordan. This could differentiate Amman from the other sites. While mass concentrations measured in this study were substantially lower than $\mathrm{PM}_{2.5}$ concentrations measured in many Asian cities [28-33], the measurements taken in Jordan, Palestine, and Israel showed that each of the eleven sampling sites had average annual $\mathrm{PM}_{2.5}$ concentrations above the US Environmental Protection Agency standard $\left(15 \mu \mathrm{g} / \mathrm{m}^{3}\right)$ and World Health Organization guidelines $\left(10 \mu \mathrm{g} / \mathrm{m}^{3}\right)$. A couple of sites (i.e., Haifa, Eilat, and Rahma) had annual averages below the new European Union standard $\left(25 \mu \mathrm{g} / \mathrm{m}^{3}\right)$ which is, in general, comparable to $\mathrm{PM}_{2.5}$ concentrations measured at urban background sites in various European and American cities, where average levels are 20 to $30 \mu \mathrm{g} / \mathrm{m}^{3}$ and 6 to $31.3 \mu \mathrm{g} / \mathrm{m}^{3}$, respectively $[34,35]$.

3.2. Dust. The dust concentration contributing to $\mathrm{PM}_{2.5}$ mass across the sites was estimated by the common metal oxides of crustal elements (i.e., $\mathrm{SiO}_{2}, \mathrm{Al}_{2} \mathrm{O}_{3}, \mathrm{~K}_{2} \mathrm{O}, \mathrm{CaO}, \mathrm{Fe}_{2} \mathrm{O}_{3}, \mathrm{TiO}_{2}$, and $\mathrm{MnO}_{2}$ ) [36] at the sites as shown in the following:

$$
\begin{aligned}
\text { Dust }= & 2.139 \times \mathrm{Si}+1.899 \times \mathrm{Al}+1.205 \times \mathrm{K}+1.4 \times \mathrm{Ca} \\
& +1.43 \times \mathrm{Fe}+1.668 \times \mathrm{Ti}+1.582 \times \mathrm{Mn} .
\end{aligned}
$$

Results from the dust calculation show that dust components contribute to $19 \%$ of total $\mathrm{PM}_{2.5}$ mass over the study period in the region, and high dust contributions to $\mathrm{PM}_{2.5}$ are observed at four of the eleven sites, ranging from $24 \%$ to $27 \%$ in Eilat, Aqaba, Amman, and Rahma (Table 1). Dust contributions for the other sites are less than the average annual contribution among all sites, ranging from $13 \%$ to $18 \%$ in Haifa and Zarqa, respectively. This level is moderately higher than 5 to $10 \%$ contributions to $\mathrm{PM}_{2.5}$ mass concentrations at 60 rural, urban, and curbside sites across Europe as well as East Asian Countries [37, 38] but is not a dominant component of the $\mathrm{PM}_{2.5}$. This is an important result of the current study, because the expectation that much of the $\mathrm{PM}_{2.5}$ is dust undermines the need to address particulate matter air pollution in this study region. In addition, $\mathrm{PM}_{2.5}$ mass levels at monitoring stations in Israel are impacted much less than the $\mathrm{PM}_{10}$ (less than $10 \mu \mathrm{m}$ aerodynamic diameter) and is elevated by a factor of 2 while $\mathrm{PM}_{10}$ can go high by a factor more than 10 to reach even 1500 and $2000 \mu \mathrm{g} / \mathrm{m}^{3}$ (data not shown). Thus, the difference in dust contribution to $\mathrm{PM}_{2.5}$ between sites can be explained. Figure 2 shows spatial and seasonal trends in dust concentrations across the sites during the sampling year. The dust concentrations exhibit a distinct seasonal variation with high enhancement in the Q2 months. Two extreme dust events on May 30th and October 9th coincided with the sampling period and resulted in elevated $\mathrm{PM}_{2.5}$ mass concentrations, with mean $\mathrm{PM}_{2.5}$ mass concentrations of $99.7 \mu \mathrm{g} / \mathrm{m}^{3}$ and $54.9 \mu \mathrm{g} / \mathrm{m}^{3}$, respectively, among all sites. Consequently, the dust components of $\mathrm{PM}_{2.5}$ were elevated across all sites during these dust events, with cross-site average of $50.3 \mu \mathrm{g} / \mathrm{m}^{3}$ and $14.0 \mu \mathrm{g} / \mathrm{m}^{3}$ for May and October, respectively. Overall, due to dust storm events between April and May, there is a significant enhancement of dust concentrations during the Q2 months in the region.

Urban dusts (i.e., crustal PM components) are typically associated with site-specific conditions, such as the type and abundance of industrial activities, nature of emissions, traffic load, traffic flow, and more [39]. Elemental ratios of dust components can be used to estimate types and/or sources of soil/dust particles [40]. In this study, mean $\mathrm{SiO}_{2}$ concentration was plotted against the mean concentration of four other crustal metal oxides for each site to evaluate the similarity of dust type in $\mathrm{PM}_{2.5}$ in the region (Figure 3). 
TABLE 1: Annual average concentrations of $\mathrm{PM}_{2.5}$ components across the eleven sampling sites, MECARS-2007 (unit: microgram per cubic meter).

\begin{tabular}{|c|c|c|c|c|c|c|c|c|c|c|}
\hline Site & Statistics & $\mathrm{PM}_{2.5}$ mass & OC & $\mathrm{EC}$ & $\mathrm{SO}_{4}{ }^{2-}$ & $\mathrm{NO}_{3}^{-}$ & $\mathrm{NH}_{4}^{+}$ & Dust & Toxic metal & Metal \\
\hline \multicolumn{11}{|l|}{ All sites } \\
\hline & Minimum & 5.6 & N.D & N.D & N.D & N.D & 0.0 & N.D & N.D & N.D \\
\hline & Mean & 28.7 & 5.3 & 2.1 & 4.6 & 1.1 & 1.8 & 5.5 & 0.1 & 0.5 \\
\hline & Std. deviation & 17.8 & 4.0 & 2.2 & 2.6 & 0.9 & 1.0 & 8.6 & 0.4 & 0.5 \\
\hline & Maximum & 162.0 & 36.2 & 16.1 & 14.9 & 8.1 & 6.8 & 75.4 & 4.8 & 3.3 \\
\hline \multicolumn{11}{|l|}{ Palestine } \\
\hline \multirow{4}{*}{ E. Jerusalem } & Minimum & 9.7 & 2.0 & 0.9 & 0.9 & 0.2 & 0.3 & 0.4 & N.D & 0.1 \\
\hline & Mean & 26.8 & 5.5 & 2.3 & 4.5 & 1.0 & 1.8 & 4.6 & 0.1 & 0.4 \\
\hline & Std. deviation & 17.1 & 4.3 & 1.4 & 2.4 & 0.7 & 0.9 & 8.1 & 0.1 & 0.4 \\
\hline & Maximum & 117.9 & 29.3 & 6.6 & 10.7 & 3.6 & 4.1 & 53.7 & 0.4 & 2.8 \\
\hline \multirow{4}{*}{ Hebron } & Minimum & 8.1 & 2.0 & 0.7 & 1.1 & 0.2 & 0.4 & 0.3 & N.D & 0.1 \\
\hline & Mean & 23.1 & 5.5 & 1.8 & 4.0 & 0.9 & 1.7 & 3.4 & 0.1 & 0.3 \\
\hline & Std. deviation & 10.8 & 2.7 & 0.9 & 2.3 & 0.6 & 0.9 & 4.0 & 0.1 & 0.2 \\
\hline & Maximum & 65.0 & 13.3 & 5.1 & 13.0 & 3.2 & 4.3 & 20.7 & 0.4 & 0.9 \\
\hline \multirow{4}{*}{ Nablus } & Minimum & 13.3 & 3.5 & 2.1 & 1.0 & 0.4 & 0.3 & 0.3 & 0.1 & 0.1 \\
\hline & Mean & 30.9 & 8.3 & 5.6 & 4.4 & 1.1 & 1.7 & 4.4 & 0.1 & 0.4 \\
\hline & Std. deviation & 12.4 & 2.9 & 1.9 & 2.5 & 0.7 & 0.9 & 6.5 & 0.1 & 0.3 \\
\hline & Maximum & 85.1 & 15.9 & 9.0 & 11.0 & 3.7 & 4.0 & 39.0 & 0.4 & 2.0 \\
\hline \multicolumn{11}{|l|}{ Jordan } \\
\hline \multirow{4}{*}{ Aqaba } & Minimum & 10.3 & 1.1 & N.D & 0.8 & 0.2 & 0.0 & N.D & N.D & N.D \\
\hline & Mean & 25.4 & 3.7 & 0.8 & 3.8 & 0.9 & 1.4 & 6.3 & 0.1 & 0.4 \\
\hline & Std. deviation & 16.5 & 1.6 & 0.6 & 1.6 & 0.5 & 0.8 & 9.5 & 0.1 & 0.4 \\
\hline & Maximum & 114.2 & 8.9 & 3.0 & 7.7 & 3.4 & 4.3 & 58.5 & 0.2 & 2.5 \\
\hline \multirow{4}{*}{ Rahma } & Minimum & 8.3 & N.D & N.D & 0.9 & 0.2 & 0.3 & 0.4 & N.D & 0.1 \\
\hline & Mean & 25.0 & 2.3 & 0.3 & 4.1 & 0.9 & 1.6 & 6.7 & 0.1 & 0.5 \\
\hline & Std. deviation & 18.7 & 1.1 & 0.3 & 2.1 & 0.6 & 0.9 & 11.2 & 0.1 & 0.5 \\
\hline & Maximum & 132.0 & 5.7 & 1.3 & 11.5 & 3.0 & 4.3 & 72.0 & 0.2 & 3.1 \\
\hline \multirow{4}{*}{ Amman } & Minimum & 12.4 & 1.8 & 0.6 & 1.6 & 0.3 & 0.6 & 0.3 & 0.1 & 0.1 \\
\hline & Mean & 40.3 & 6.7 & 2.5 & 4.9 & 1.2 & 2.0 & 10.7 & 0.1 & 0.7 \\
\hline & Std. deviation & 25.4 & 4.0 & 1.7 & 2.3 & 0.7 & 1.1 & 13.7 & 0.1 & 0.5 \\
\hline & Maximum & 162.0 & 20.4 & 7.5 & 11.5 & 3.9 & 5.8 & 75.4 & 0.5 & 3.0 \\
\hline \multirow{4}{*}{ Zarqa } & Minimum & 12.6 & 2.8 & 0.9 & 1.3 & 0.1 & 0.5 & 0.5 & 0.1 & 0.1 \\
\hline & Mean & 37.5 & 9.4 & 4.4 & 5.4 & 1.4 & 2.1 & 6.9 & 0.7 & 0.6 \\
\hline & Std. deviation & 19.4 & 5.8 & 3.6 & 2.5 & 1.3 & 1.1 & 9.3 & 1.1 & 0.5 \\
\hline & Maximum & 113.0 & 36.2 & 16.1 & 11.8 & 7.6 & 5.9 & 58.9 & 4.8 & 2.7 \\
\hline \multicolumn{11}{|l|}{ Israel } \\
\hline \multirow{4}{*}{ Eilat } & Minimum & 5.6 & 1.2 & N.D & N.D & N.D & 0.4 & 0.6 & 0.1 & 0.1 \\
\hline & Mean & 20.6 & 3.3 & 0.7 & 3.7 & 0.8 & 1.5 & 4.9 & 0.1 & 0.4 \\
\hline & Std. deviation & 9.6 & 1.5 & 0.5 & 1.8 & 0.8 & 0.9 & 5.2 & 0.1 & 0.3 \\
\hline & Maximum & 53.7 & 7.1 & 1.6 & 7.2 & 4.8 & 4.9 & 23.6 & 0.2 & 1.3 \\
\hline \multirow{4}{*}{ W. Jerusalem } & Minimum & 10.3 & 1.4 & N.D & 0.9 & 0.2 & 0.3 & 0.2 & N.D & 0.1 \\
\hline & Mean & 25.7 & 4.6 & 1.2 & 4.9 & 1.1 & 2.0 & 4.5 & 0.1 & 0.4 \\
\hline & Std. deviation & 18.2 & 4.9 & 1.2 & 2.8 & 0.7 & 1.0 & 7.7 & 0.1 & 0.5 \\
\hline & Maximum & 116.6 & 36.2 & 8.8 & 14.2 & 3.0 & 4.7 & 50.2 & 0.6 & 2.9 \\
\hline \multirow{4}{*}{ Tel Aviv } & Minimum & 13.0 & 1.6 & N.D & 1.2 & N.D & 0.4 & 0.4 & 0.1 & 0.2 \\
\hline & Mean & 32.2 & 4.8 & 1.6 & 5.5 & 1.4 & 2.2 & 4.5 & 0.1 & 0.8 \\
\hline & Std. deviation & 12.5 & 2.6 & 0.9 & 3.3 & 1.6 & 1.3 & 3.9 & 0.1 & 0.7 \\
\hline & Maximum & 80.7 & 12.7 & 3.7 & 14.9 & 8.1 & 6.8 & 17.5 & 0.2 & 3.3 \\
\hline
\end{tabular}


TABle 1: Continued.

\begin{tabular}{ccccccccccc}
\hline Site & Statistics & $\mathrm{PM}_{2.5}$ mass & $\mathrm{OC}$ & $\mathrm{EC}$ & $\mathrm{SO}_{4}{ }^{2-}$ & $\mathrm{NO}_{3}{ }^{-}$ & $\mathrm{NH}_{4}{ }^{+}$ & Dust & Toxic metal & Metal \\
\hline \multirow{4}{*}{ Haifa } & Minimum & 7.8 & 1.1 & $\mathrm{~N} . \mathrm{D}$ & 0.7 & $\mathrm{~N} . \mathrm{D}$ & 0.0 & 0.2 & N.D & 0.1 \\
& Mean & 24.4 & 3.4 & 1.0 & 5.4 & 0.8 & 1.9 & 3.1 & 0.1 & 0.4 \\
& Std. deviation & 17.0 & 2.9 & 0.7 & 3.3 & 0.6 & 1.1 & 6.8 & 0.1 & 0.4 \\
& Maximum & 106.8 & 22.6 & 4.8 & 14.9 & 3.1 & 5.6 & 48.5 & 0.4 & 2.8 \\
\hline
\end{tabular}

N.D represents not detected.

There are similar ratios and strong spatiotemporal correlations for $\mathrm{K}_{2} \mathrm{O} / \mathrm{SiO}_{2}, \mathrm{Fe}_{2} \mathrm{O}_{3} / \mathrm{SiO}_{2}$, and $\mathrm{Al}_{2} \mathrm{O}_{3} / \mathrm{SiO}_{2}$ across the sites, implying that these dust components are relatively homogenous and no specific local sources are contributing to these components throughout the entire region. For the $\mathrm{CaO} / \mathrm{SiO}_{2}$ ratio, Amman and Zarqa sites had higher values than other sites, which indicate that site-specific local emissions contribute to additional $\mathrm{Ca}$ mass at both sites. For this reason, we have excluded these two sites in the regression of $\mathrm{CaO}$ and $\mathrm{SiO}_{2}$ shown in Figure 3. In general, $\mathrm{Ca} / \mathrm{Si}$ mass ratio estimated from chemical analyses for paved, unpaved road and soil has been about $0.3-0.6[40,41]$. While $\mathrm{Ca}$ is the fifth most abundant element in earth metals, it is also largely emitted from anthropogenic activities including cement kilns and limestone quarries, as well as coal fire power plants [42]. It should be noted that there was a large construction in Amman during this study period [19], thus, the heavy use of construction-related gypsum (i.e., $\mathrm{CaSO}_{4} \cdot \mathrm{H}_{2} \mathrm{O}$ ) might be affecting high $\mathrm{Ca}$ concentrations in Amman relative to the other sites. The Zarqa site is located $15 \mathrm{~km}$ to the northeast of the Amman site and because of this geographic proximity, it is possible that the calcium-rich dust emitted from the construction activity in Amman may also have affected the $\mathrm{Ca}$ level in Zarqa [19]. In addition, there are numerous industrial processing sites in Zarqa, which may be contributing to additional $\mathrm{Ca}$.

3.3. Inorganic Water Soluble Ions. Inorganic water soluble ions (i.e., $\mathrm{SO}_{4}{ }^{2-}, \mathrm{NO}_{3}{ }^{-}, \mathrm{Cl}^{-}, \mathrm{NH}_{4}{ }^{+}, \mathrm{Na}^{+}$, and $\mathrm{K}^{+}$) detected by ion chromatograph showed that annual mean concentrations for total ion matters varied by site. High ion levels were present at Amman, Zarqa, and Haifa, where a large number of local and heavy industrial activities exist relative to the other sites (Figure S2). The ionic mass fraction contributed approximately $28 \%$ of the total $\mathrm{PM}_{2.5}$ mass across all sites, with a range of $21 \%$ in Amman to $37 \%$ in Haifa. In particular, key ionic ions were $\mathrm{SO}_{4}{ }^{2-}$ and $\mathrm{NH}_{4}{ }^{+}$, explaining around $23 \%$ of total $\mathrm{PM}_{2.5}$ mass in the region (Table S2). The total ion contribution to the $\mathrm{PM}_{2.5}$ mass in this study appears to be lower than those from previous studies conducted at many urban and rural sites in Europe, North America, and Asia, where secondary sulfate, nitrate, and ammonium together (i.e., $\mathrm{SO}_{4}{ }^{2-}, \mathrm{NO}_{3}{ }^{-}$, and $\mathrm{NH}_{4}{ }^{+}$) account for $50 \%$ of the $\mathrm{PM}_{2.5}$ mass concentrations [38, 43-47]. This difference seems to be due primarily to the lower concentrations of $\mathrm{NO}_{3}{ }^{-}$, which is formed through a photochemical reaction of $\mathrm{NO}_{x}$.

In this study, $\mathrm{SO}_{4}{ }^{2-}$ and $\mathrm{NH}_{4}{ }^{+}$showed significantly high $(r>0.83)$ correlations among the intercorrelation for each pair of ion species at almost every site, whereas the relationship between $\mathrm{NO}_{3}{ }^{-}$and $\mathrm{NH}_{4}{ }^{+}$was not statistically significant (Table $\mathrm{S} 4$ ). In addition, the ambient particulate concentration ratio of $\mathrm{NH}_{4}{ }^{+}$to $\mathrm{SO}_{4}{ }^{2-}$ less than 1.5 indicates an ammonium poor ambient atmosphere, which limits the formation of ammonium nitrate concentrations [14]. In this study, the ratio of $\mathrm{NH}_{4}{ }^{+} / \mathrm{SO}_{4}{ }^{2-}$ shows around 0.4 . Therefore, it could be explained that after ammonia was fully neutralized by formation of ammonium sulfate aerosols, not enough ammonia remained $\left(\mathrm{NH}_{3}\right.$-limited environment) to form fine particles of ammonium nitrate in the region.

The mass ratio $\mathrm{NO}_{3}{ }^{-} / \mathrm{SO}_{4}{ }^{2-}$ has been used as an indicator of the relative prevalence of stationary and mobile sources of sulfur and nitrogen in the atmosphere of polluted areas [32, 48-50]. Wang et al. [51] report that the estimated ratios of $\mathrm{NO}_{x}$ to $\mathrm{SO}_{x}$ from the emissions of gasoline and diesel fuel burning are $13: 1$ and $8: 1$, respectively, and are $1: 2$ from coal burning through emission factors and demonstrate that it is reasonable to use $\mathrm{SO}_{4}{ }^{2-}$ as an indicator of stationary emission and $\mathrm{NO}_{3}{ }^{-}$of mobile emission. Therefore, ratio values between 0.30 and 0.50 were ascribed to industrial use of high sulfur coal [49], while lower values $(0.13 \pm 0.06)$ were inferred as indicating predominance of stationary source emissions over traffic emissions [50]. The $\mathrm{NO}_{3}{ }^{-} / \mathrm{SO}_{4}{ }^{2-}$ ratio in this study ranged from 0.15 at Haifa to 0.28 at Tel Aviv. This suggests that the contributions of mobile emissions to fine particles at all sites are less significant than those of industrial origin. Overall, ammonium nitrate concentrations are not found to be important for $\mathrm{PM}_{2.5}$ in this study region.

Seasonal trends in $\mathrm{SO}_{4}{ }^{2-}$ and $\mathrm{NO}_{3}{ }^{-}$concentrations for the 11 sites are presented in Figures S4-S6. As expected, the $\mathrm{SO}_{4}{ }^{2-}$ concentrations were highest between April and August, whereas the $\mathrm{NO}_{3}{ }^{-}$exhibited lowest concentrations in these months. In general, the oxidation reaction of $\mathrm{SO}_{2}$ via $\mathrm{OH}$ radical is enhanced in summer due to strong solar radiation, resulting in high $\mathrm{SO}_{4}{ }^{2-}$ concentrations in summer [52]. The observed seasonal trends of these two ions over the study region are well in accord with documented evidence. Amman showed no strong seasonality in the $\mathrm{SO}_{4}{ }^{2-}$ concentrations due to local construction activities as explained before.

3.4. Ion Balance. The neutralization of the acidity present in aerosols is important to aerosol hygroscopicity, heterogeneous chemistry, and gas/particle partitioning. To better understand the degree of neutralization of aerosols, an ion balance can be investigated to compare cation and anion concentrations in the aerosol [44]. The aerosol composition in the sampled region shows a broad variability, with the 




FIGURE 2: Seasonal trends of dust concentrations across sites. 


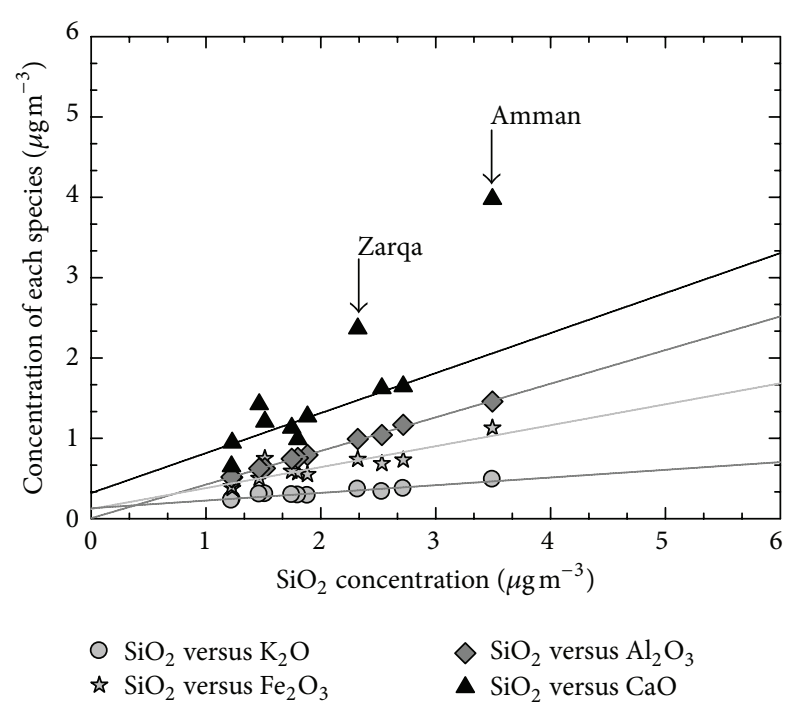

FIGURE 3: Comparison of dust oxides between sampling sites (both Amman and Zarqa data points were excluded from the $\mathrm{CaO}$ and $\mathrm{SiO}_{2}$ regression).

mass concentrations of each individual species varying up to an order of magnitude throughout the sampling period. When total equivalents of cations $\left(\sum \mathrm{Na}^{+}+\mathrm{K}^{+}+\mathrm{NH}_{4}^{+}\right)$are plotted against total equivalents of anions $\left(\sum \mathrm{Cl}^{-}+\mathrm{NO}_{3}{ }^{-}+\right.$ $\left.2 \mathrm{SO}_{4}{ }^{2-}\right)$ as shown in Figure 4, the slope of the regression lines for Q1, Q2, Q3, and Q4 was $0.93\left(r^{2}=0.83\right), 0.97\left(r^{2}\right.$ $=0.81), 0.93\left(r^{2}=0.92\right)$, and $0.85\left(r^{2}=0.89\right)$, respectively. All seasons except for the Q4 showed that the slope is not very different from 1.0, which indicates all cations considered are fully neutralized for sulfate and nitrate aerosols. For the Q4, the slope of the regression line is different from 1.0, weighted towards total anions which means anions are not completely neutralized by considered cations. This difference is most likely from reduced emissions of ammonia associated lower temperatures and differences in agricultural practices in the Q4 months.

3.5. Trace Elements. Trace elements including heavy metals are significant components of PM in urban environments. These elements are of particular concern due to their persistence in the environmental media and their human toxicity $[53,54]$. In particular, nonbiodegradability of heavy metals leads to their accumulation in the environment [55].

A cluster analysis [56] is an exploratory data analysis tool that yields groups of elements that have common sources or common meteorological factors controlling their concentrations. Metals from samples with $90 \%$ of their concentrations below the detection limits were eliminated from the cluster analysis to increase analytical precision. 18 trace elements: $\mathrm{Al}, \mathrm{Si}, \mathrm{P}, \mathrm{S}, \mathrm{Cl}, \mathrm{K}, \mathrm{Ca}, \mathrm{Ti}, \mathrm{V}, \mathrm{Mn}, \mathrm{Fe}, \mathrm{Ni}, \mathrm{Cu}, \mathrm{Zn}, \mathrm{Br}, \mathrm{Sr}$, $\mathrm{Yt}$, and $\mathrm{Pb}$, were used in the analysis. Table S3 summarizes annual average concentrations of each metal across eleven sites. Results from the analysis found that there are three groups of a common source and one group of a site-specific source among the observed trace elements across the sites (Table 2).
Group 1 is characterized by high loading of $\mathrm{Al}, \mathrm{Si}, \mathrm{Fe}$, $\mathrm{Mn}, \mathrm{Ca}, \mathrm{K}$, and $\mathrm{Sr}$, most of which are crustal elements, and appears to indicate dust aerosol impacts in the region. Group 2 is strongly correlated with sulfur and phosphate. This group represents industrial activities including coal fired power plants as well as regional loading of $\mathrm{SO}_{4}{ }^{2-}$ in this study area. Because phosphorus pentasulfide $\left(\mathrm{P}_{2} \mathrm{~S}_{5}\right)$ is commonly used for lubricating oil and grease additives and for organophosphorus materials [57], it is possible that this specific source contributes to the high correlation between $\mathrm{P}$ and $\mathrm{S}$ in this group. Group 3 is characterized by strong correlations between $\mathrm{Pb}, \mathrm{Zn}$, and $\mathrm{Br}$. In general, the increased concentrations and/or the strong correlation between $\mathrm{Pb}, \mathrm{Zn}$, and $\mathrm{Br}$ are found to be in traffic source profiles, including tire wear, brake lining, catalyst deterioration, and fuel combustion emissions [58-60]. Therefore, this group may be associated with the effects of mobile emissions in the region. Group 4 is categorized by $\mathrm{Ni}$ and $\mathrm{V}$, which are predominantly emitted from fuel oil combustion, and thus represents fuel oil use in the region. This group is only identified in East Jerusalem, Rahma, Zarqa, and Haifa, suggesting site-specific local emissions. The results of chemical components analysis revealed that toxic metals in $\mathrm{PM}_{2.5}$ varied significantly across sample sites, with highest concentrations in Haifa and Zarqa. Haifa had significantly higher concentrations of nickel and zinc compared to the other sites which is likely a result of the combustion of residual oils used by ships, the stationary combustion of fuel oil, or by industrial activity. Likewise, Zarqa had significantly higher concentrations of lead in the $\mathrm{PM}_{2.5}$ samples than any other site, including Aqaba and Amman, suggesting that the high level of lead in Zarqa is not attributable to leaded gasoline fuel, a type of fuel still used in Jordan during the study period. However, for Rahma, there is high loading of $\mathrm{Ni}$ and $\mathrm{Br}$ in the group 4. The Rahma sample site is located in a desert area, representing a relatively remote rural environment. This site received high concentrations of $\mathrm{Ni}$ and $\mathrm{Br}$ which may be associated with well-known industrial sources of $\mathrm{Br}$ near the Dead Sea and sea salt which contains traces of $\mathrm{Br}$. This site-specific $\mathrm{Br}$ emission can impact the ambient particles in Rahma during regional transportation, but the correct source characterization could not be captured by this cluster analysis. Further research with other air quality receptor methods is needed to better understand the sources.

3.6. Carbonaceous Species. Carbonaceous materials in $\mathrm{PM}_{2.5}$ are important components in both urban and rural areas due to comprising from 10 to $70 \%$ of total $\mathrm{PM}_{2.5}$ mass $[61,62]$. Carbonaceous aerosols are directly emitted from diverse sources and formed by photochemical reactions, thus understanding of them and their sources is very important.

The statistical presentation of the analytical results for carbonaceous species present in $\mathrm{PM}_{2.5}$ samples is reported in Table 1. Carbonaceous material was the dominant contributor (50-60\%) to $\mathrm{PM}_{2.5}$ mass in this study. The highest levels of $\mathrm{PM}_{2.5}$ OC were observed in Zarqa, Nablus, and Amman (Figure S3). OC and EC concentrations are the largest contributors to $\mathrm{PM}_{2.5}$ in the region with the possible exceptions of Eilat, Aqaba, and Rahma. This regional OC 

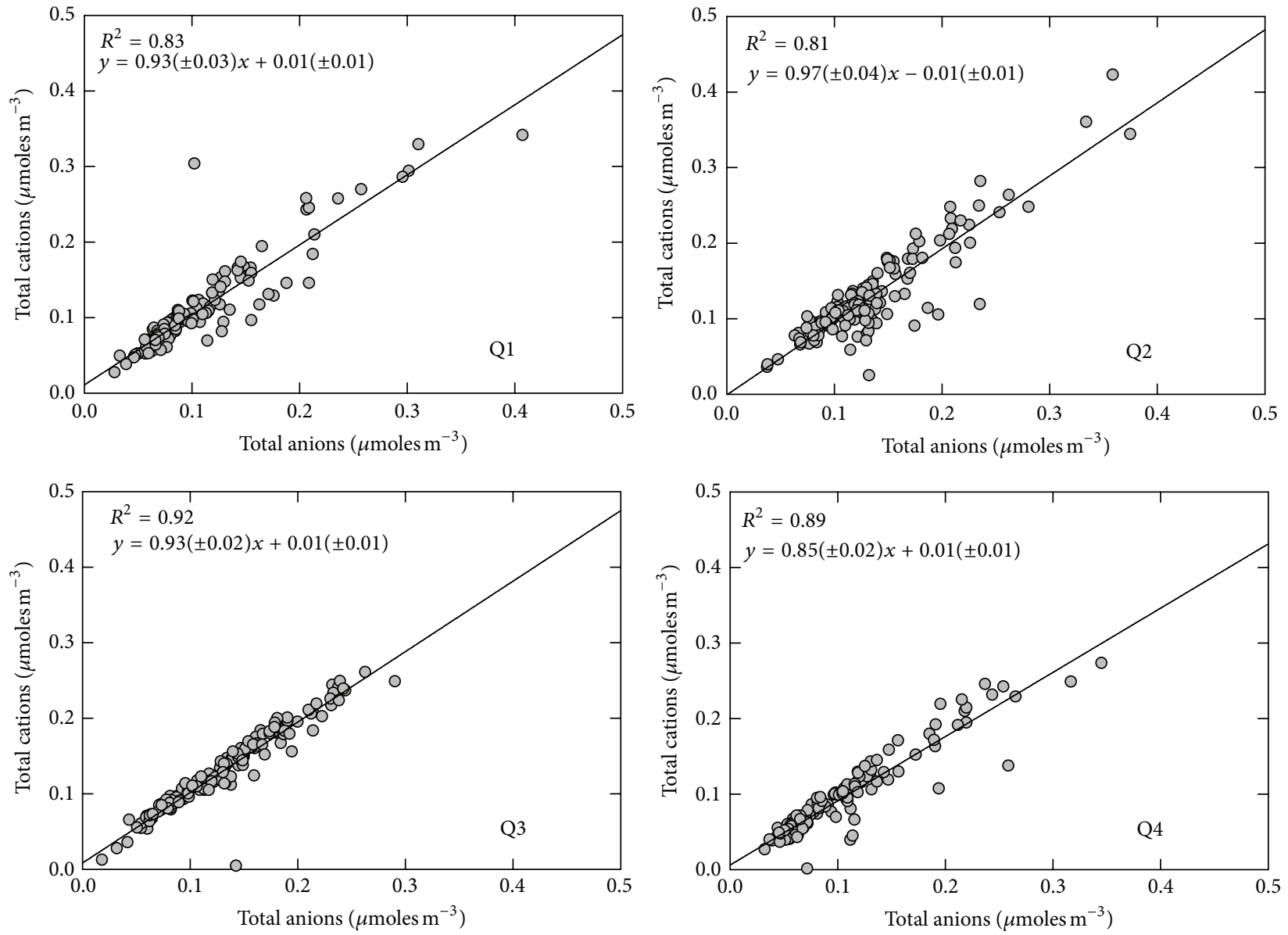

FIgURE 4: Correlations between a total of cations and anions over the study period.

TABLE 2: Cluster analysis results for metals observed at each site.

\begin{tabular}{|c|c|c|c|c|c|}
\hline \multicolumn{2}{|c|}{ Site } & Group 1 & Group 2 & Group 3 & Group 4 \\
\hline \multirow{3}{*}{ Palestine } & E. Jerusalem & $\mathrm{Al}, \mathrm{Ti}, \mathrm{Si}, \mathrm{Fe}, \mathrm{Mn}, \mathrm{Ca}, \mathrm{K}, \mathrm{Sr}$ & $\mathrm{P}, \mathrm{S}$ & $\mathrm{Pb}, \mathrm{Br}, \mathrm{Zn}$ & $\mathrm{V}, \mathrm{Ni}$ \\
\hline & Hebron & $\mathrm{Al}, \mathrm{Si}, \mathrm{Fe}, \mathrm{Ti}, \mathrm{Mn}, \mathrm{K}, \mathrm{Ca}, \mathrm{Sr}$ & $\mathrm{P}, \mathrm{S}$ & & \\
\hline & Nablus & $\mathrm{Al}, \mathrm{Si}, \mathrm{Ti}, \mathrm{Fe}, \mathrm{Mn}, \mathrm{K}, \mathrm{Ca}, \mathrm{Sr}$ & $\mathrm{P}, \mathrm{S}$ & $\mathrm{Pb}, \mathrm{Cu}, \mathrm{Br}, \mathrm{Yt}$ & \\
\hline \multirow{4}{*}{ Jordan } & Aqaba & $\mathrm{Al}, \mathrm{Si}, \mathrm{Fe}, \mathrm{Ti}, \mathrm{Ca}, \mathrm{Mn}, \mathrm{K}, \mathrm{Sr}$ & & $\mathrm{Pb}, \mathrm{Zn}$ & \\
\hline & Rahma & $\mathrm{Al}, \mathrm{Si}, \mathrm{Ti}, \mathrm{Fe}, \mathrm{Ca}, \mathrm{Mn}, \mathrm{K}, \mathrm{Sr}$ & $\mathrm{P}, \mathrm{S}$ & $\mathrm{Pb}, \mathrm{Zn}$ & $\mathrm{Ni}, \mathrm{Br}$ \\
\hline & Amman & $\mathrm{Al}, \mathrm{Si}, \mathrm{Fe}, \mathrm{Ti}, \mathrm{Mn}, \mathrm{K}, \mathrm{Ca}, \mathrm{Sr}, \mathrm{V}$ & $\mathrm{P}, \mathrm{S}$ & $\mathrm{Pb}, \mathrm{Br}$ & \\
\hline & Zarqa & $\mathrm{Al}, \mathrm{Si}, \mathrm{Ti}, \mathrm{Fe}, \mathrm{K}, \mathrm{Sr}, \mathrm{Ca}$ & $\mathrm{P}, \mathrm{S}$ & $\mathrm{Pb}, \mathrm{Yt}, \mathrm{Cl}, \mathrm{Br}$ & $\mathrm{V}, \mathrm{Ni}$ \\
\hline \multirow{4}{*}{ Israel } & Eilat & $\mathrm{Al}, \mathrm{Si}, \mathrm{Ti}, \mathrm{Fe}, \mathrm{Mn}, \mathrm{Ca}, \mathrm{K}, \mathrm{Sr}$ & $\mathrm{P}, \mathrm{S}$ & $\mathrm{Pb}, \mathrm{Zn}$ & \\
\hline & W. Jerusalem & $\mathrm{Al}, \mathrm{Si}, \mathrm{Ti}, \mathrm{Fe}, \mathrm{Mn}, \mathrm{Ca}, \mathrm{K}, \mathrm{Sr}$ & $\mathrm{P}, \mathrm{S}$ & $\mathrm{Pb}, \mathrm{Br}, \mathrm{Zn}$ & \\
\hline & Tel Aviv & $\mathrm{Al}, \mathrm{Si}, \mathrm{Ti}, \mathrm{Fe}, \mathrm{Mn}, \mathrm{K}, \mathrm{Sr}$ & $\mathrm{P}, \mathrm{S}$ & $\mathrm{Pb}, \mathrm{Zn}$ & \\
\hline & Haifa & $\mathrm{Al}, \mathrm{Si}, \mathrm{Ti}, \mathrm{Fe}, \mathrm{Mn}, \mathrm{Ca}, \mathrm{K}, \mathrm{Sr}$ & $\mathrm{P}, \mathrm{S}$ & $\mathrm{Pb}, \mathrm{Br}$ & $\mathrm{V}, \mathrm{Ni}$ \\
\hline
\end{tabular}

and EC $\mathrm{PM}_{2.5}$ contribution is similar to Europe and North America. Average $\mathrm{OC}$ and EC concentrations were $5.30 \pm 4.03$ and $2.06 \pm 8.93 \mu \mathrm{g} / \mathrm{m}^{3}$, respectively with a $2.57 \pm 2.08 \mathrm{OC} / \mathrm{EC}$ ratio. The OC and EC concentrations in Tel Aviv were 38\% and 50\% higher than in Haifa. Similar results were reported in Osaka, Japan [63], which showed an average of 5.2 and $3.4 \mu \mathrm{g} / \mathrm{m}^{3}$ OC and EC, respectively, and an OC/EC ratio of 1.53 .
For OC and EC, between-site correlations among the sites were weak, representing large heterogeneity among the sites due to site specific local emission sources. Previously published work has extensively addressed the spatiotemporal trends of both OC and EC of $\mathrm{PM}_{2.5}$ in the Middle East [19]. Generally, the measured amount of carbonaceous components tended to increase from summer to winter. EC is typically emitted from diesel engines and exhibits 


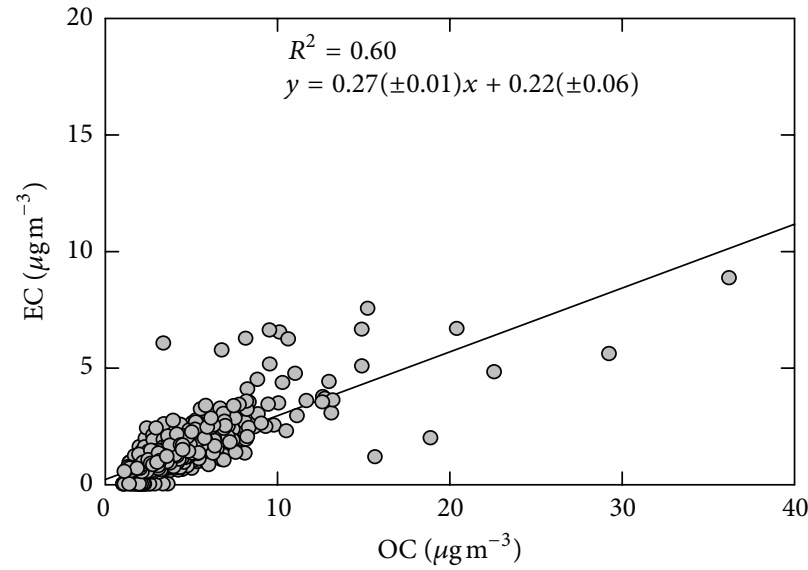

(a)

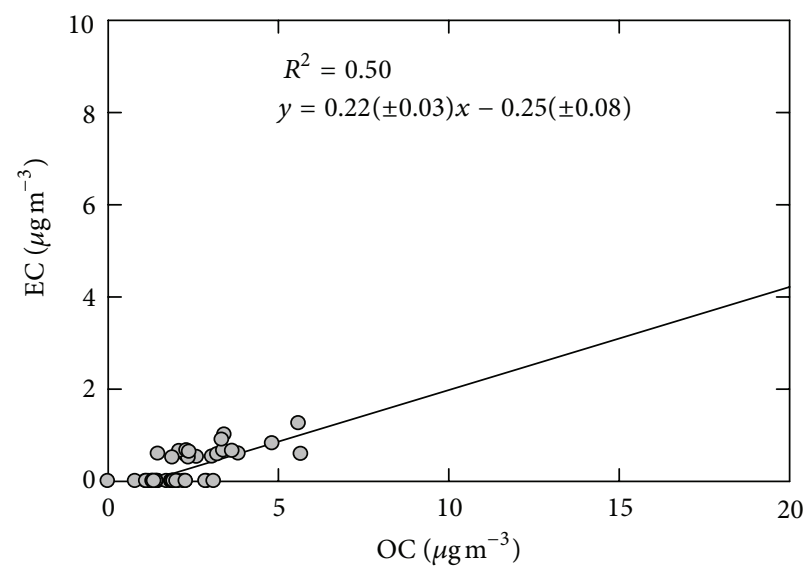

(c)

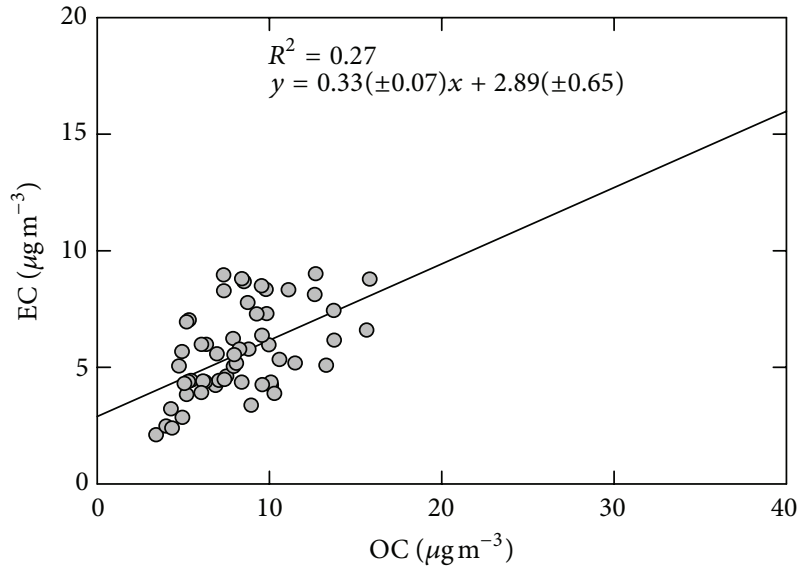

(b)

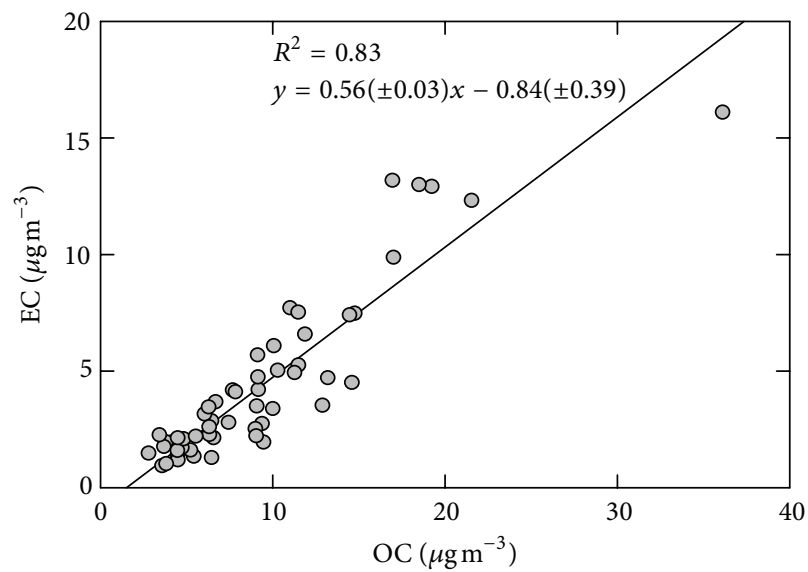

(d)

FIGURE 5: Comparison between OC and EC concentrations (graph (a) includes East Jerusalem, Hebron, Aqaba, Amman, Haifa, Eilat, Tel Aviv, and West Jerusalem; graphs (b, c, and d) indicate Nablus, Rachma, and Zarqa, resp.).

high intraurban spatial heterogeneity given its local, primary source contributions. The present findings showed moderate to strong correlations $\left(R^{2}>0.65\right)$ in EC concentrations among the large urban sites of West Jerusalem, Tel Aviv, and Amman. Moreover, the correlations were strong despite absolute differences in $\mathrm{PM}_{2.5}$ EC concentrations measured in each of these cities. The high EC correlations in these urban centers may be due to synoptic conditions (i.e., the influence of stagnation episodes) and commuter activity patterns. Similarly, weaker EC correlations among the other sites may point to the impact of specific EC sources beyond those of traffic-related emissions.

OC concentrations were corrected by a factor of 1.8 in order to assess the particulate organic matter (OM). This correction factor utilized corresponds to mildly oxidized organic material in the urban environment $[64,65]$. OM concentrations were approximately five times greater than observed EC concentrations and ranged from $3.94 \mu \mathrm{g} / \mathrm{m}^{3}$ to $15.40 \mu \mathrm{g} / \mathrm{m}^{3}$, resulting in an annual average of $9.54 \mu \mathrm{g} / \mathrm{m}^{3}$. $\mathrm{OM}$ was the third most abundant component of $\mathrm{PM}_{2.5}$ across sampling sites. In comparison, the OM annual average was greater than the $3.0 \mu \mathrm{g} / \mathrm{m}^{3}$ measurement taken in Helsinki, Finland [66]; but lower than those measured in Sihwa, Korea [31], Seoul, Korea [67], Kaohsiung, Taiwan [29], and Shanghai [33], where values ranged from $9.8 \mu \mathrm{g} / \mathrm{m}^{3}$ to $15.4 \mu \mathrm{g} / \mathrm{m}^{3}$. The relationship between OM and EC carbon can provide some indication of the origin of carbonaceous particles [68, 69]. The OM to EC correlation $\left(R^{2}=0.80\right)$ was strong compared to other studies $[28,31,67]$.

EC which is only emitted from combustion sources is often related to primary OC, and the relationship between two species can provide insight into their origins [62]. Previous studies have shown that OC and EC correlations at urban areas are higher than rural areas due to predominant urban activities, mostly motor vehicle emissions [70, 71]. Concentrations of EC are plotted against the corresponding OC concentrations for categorized sampling sites in Figure 5. Correlations are generally high $(r>0.5)$ at most sites where both EC and OC levels appear to be influenced by the same primary sources. However, there is lower correlation at Nablus site compared to the other sites due probably to a large amount of biogenic sources and potential gas-phase 


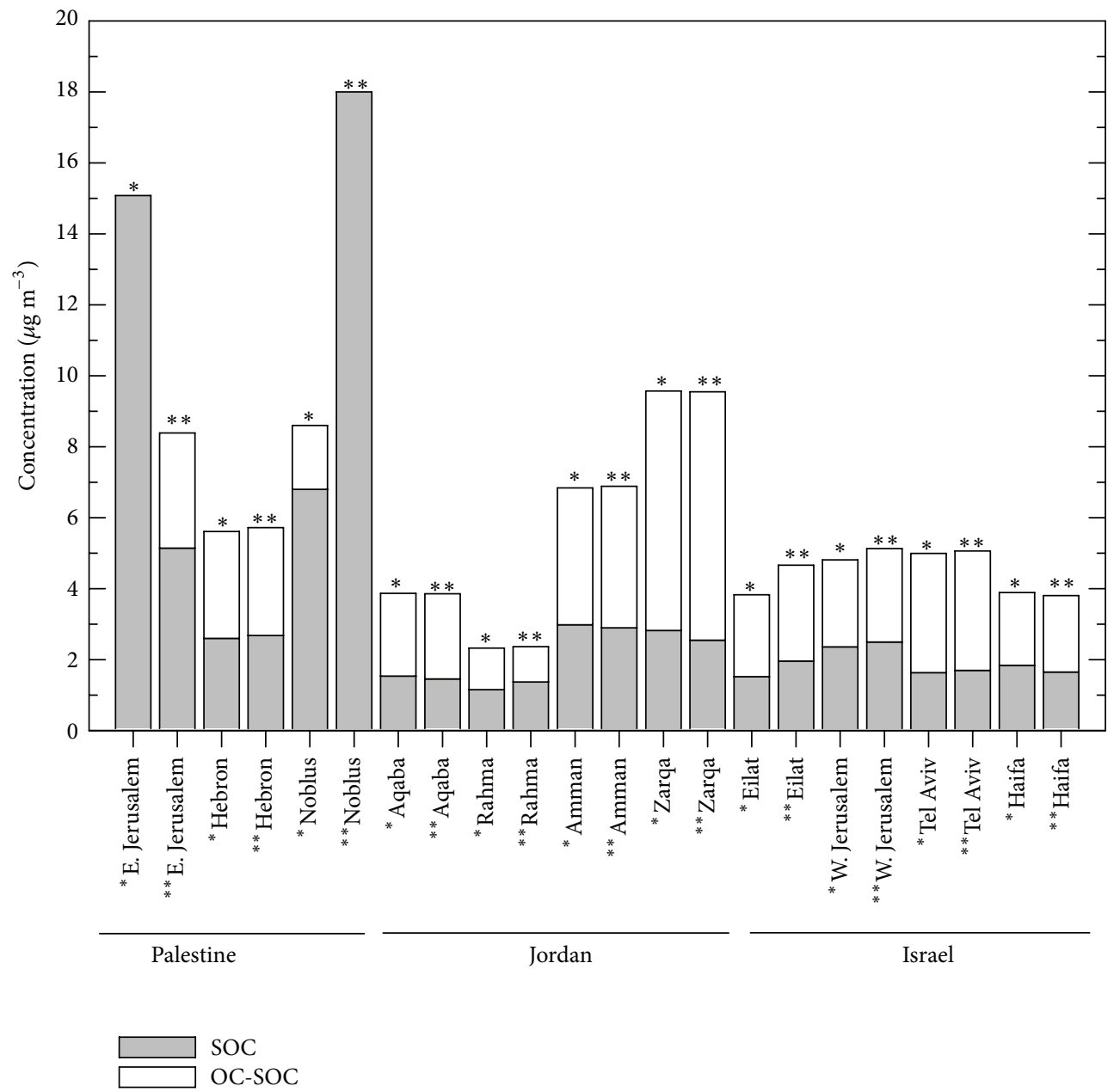

FIGURE 6: Calculated secondary organic aerosol during the study period $\left({ }^{*}\right.$; lowest $5 \%$ of OC/EC ratio for Deming regression $(n=4$ for each site), ${ }^{* *}$; lowest $10 \%$ of OC/EC ratio for Deming regression $(n=6$ for each site) $)$.

volatile organic compounds in Nablus. More details on the sources of OC and EC at these sites have been presented by von Schneidemesser et al. [21].

3.7. Secondary Organic Carbon (SOC) Estimation. Because OC can be derived from emitted particles as well as secondary organic aerosol, it was important to confirm the contributions of the primary and secondary organic carbon to carbonaceous aerosol for control of particulate pollution. Secondary organic carbon (SOC) is often a significant portion of OC in PM. Quantification of SOC is difficult because of the limited understanding of the molecular composition of SOC and the presence of a large and unknown number of individual secondary organic products. The concentration levels and seasonal patterns of SOC in the 11 sampling sites were examined by the EC tracer method $[29,66,72]$. In this method, SOC is calculated as follows:

$$
\mathrm{SOC}=\mathrm{OC}-\left(\left[\frac{\mathrm{OC}}{\mathrm{EC}}\right]_{\text {prim }} \times \mathrm{EC}+\mathrm{OC}_{\text {non-combustion }}\right) .
$$

In this equation, EC is adopted as a "tracer" for calculating the abundance of primary OC based on EC being primary in origin and $\mathrm{EC}$ and $\mathrm{OC}$ having common emission sources $[64,69,72]$. A ratio of OC/EC that is characteristic of primary emissions, called $(\mathrm{OC} / \mathrm{EC})_{\text {prim }}$, hereafter, is used to estimate SOC. Ambient OC/EC exceeding the $(\mathrm{OC} / \mathrm{EC})_{\text {prim }}$ ratio is attributed to SOC. $\mathrm{OC}_{\text {non-combustion }}$ represents primary noncombustion emissions. A linear regression of a subset of data was applied in order to determine the value of $(\mathrm{OC} / \mathrm{EC})_{\text {prim }}$ and $\mathrm{OC}_{\text {non-combustion. }}$. From the regression equation, $(\mathrm{OC} / \mathrm{EC})_{\text {prim }}$ was determined as the slope and $\mathrm{OC}_{\text {non-combustion }}$ as the $y$-intercept.

Due to the fact that photochemistry is important throughout the year in the Middle East, the minimum OC/EC ratio was estimated as the average of the lowest $5 \%$ of the OC/EC at each site and the lowest $10 \%$ of the OC/EC values at each site. Both approaches were used to evaluate the sensitivity of the calculation.

As seen in Figure 6, the 5\% and 10\% assumption yielded virtually the same result for all sites except East Jerusalem and Nablus. The poor agreement between estimation approaches for these two sites suggests that the $(\mathrm{OC} / \mathrm{EC})_{\text {prim }}$ at these two sites varies over time due to different impacts of sources. 
The average SOC level at all sites excluding East Jerusalem and Nablus for the entire sampling period was $2.71 \mu \mathrm{gC} / \mathrm{m}^{3}$, contributing to $55.48 \%$ of the OC aerosol loadings. On a mass basis, the secondary organic aerosol (SOA) contributed $17.20 \%$ of the $\mathrm{PM}_{2.5}$ mass, when using a factor of 1.8 to convert SOC to SOA mass [64].

This estimation is in agreement with measurements in other studies of urban areas $[64,69,72]$. These results suggest that the formation of SOA due to the gas/particle conversion of gaseous hydrocarbon precursors is significant in urban locations and demonstrates the importance of identifying SOC precursors for effective reduction of aerosol loadings.

3.8. Mass Closure. Knowledge of the chemical composition of atmospheric aerosols and mass closure studies in the Middle East are needed for scientific and policy reasons. Aerosol chemical mass closure calculations were performed for the $\mathrm{PM}_{2.5}$ aerosol, for each of the 11 parallel samplings. The following eight aerosol components were used to calculate the $\mathrm{PM}_{2.5}$ mass closure which was then compared to the gravimetrically calculated $\mathrm{PM}_{2.5}$ mass: (1) $\mathrm{OM}$, which was estimated by multiplying the OC by a factor of 1.8 [64]; (2) EC; (3) sulfate; (4) nitrate; (5) ammonium; (6) sea salt, estimated as $[\mathrm{Cl}]+1.4486[\mathrm{Na}]$, where 1.4486 is the ratio of the concentration of all elements except $\mathrm{Cl}$ to the $\mathrm{Na}$ concentration in sea salt [73]; (7) dust, estimated as 1.899[Al] $+2.138[\mathrm{Si}]+1.400[\mathrm{Ca}]+1.205[\mathrm{~K}]+1.668[\mathrm{Ti}]+1.430[\mathrm{Fe}]$ $+1.582[\mathrm{Mn}]$; and (8) other elements, which are the sum of the mass of all noncrustal/nonsea-salt elements measured by PIXE (S and K were excluded from this sum). Sulfate, nitrate, ammonium, and sea salt were obtained from the IC data of the $\mathrm{PM}_{2.5}$ samples.

The relative contribution of identified chemical classes to the $\mathrm{PM}_{2.5}$ mass at each site is shown in Figure 7. The average concentrations of the eight aerosol components among all sites were as follows: $\mathrm{OM}=9.54 \mu \mathrm{g} / \mathrm{m}^{3}, \mathrm{EC}=2.07 \mu \mathrm{g} / \mathrm{m}^{3}$, ammonium $=1.83 \mu \mathrm{g} / \mathrm{m}^{3}$, nitrate $=1.06 \mu \mathrm{g} / \mathrm{m}^{3}$, sulfate $=$ $4.65 \mu \mathrm{g} / \mathrm{m}^{3}$, sea salt $=0.71 \mu \mathrm{g} / \mathrm{m}^{3}$, dust $=5.47 \mu \mathrm{g} / \mathrm{m}^{3}$, and other elements $=0.20 \mu \mathrm{g} / \mathrm{m}^{3}$. The average total $\mathrm{PM}_{2.5}$ mass based on these 8 components was $25.53 \mu \mathrm{g} / \mathrm{m}^{3}$ while the average gravimetric $\mathrm{PM}_{2.5}$ mass for all sites was $28.67 \mu \mathrm{g} / \mathrm{m}^{3}$. Approximately $3.14 \mu \mathrm{g} / \mathrm{m}^{3}$ or $10.96 \%$ of the $\mathrm{PM}_{2.5}$ mass was not accounted by this calculation. The percentage attributions of the gravimetric $\mathrm{PM}_{2.5}$ mass to each of the eight components types are given in Figure 7.

Relative contributions reflect differences in emission sources and processes controlling the aerosol composition [74]. The $\mathrm{PM}_{2.5}$ profiles varied among the eleven sites. Mineral components dominated the $\mathrm{PM}_{2.5}$ profile at Aqaba, Amman, Rachma, Tel Aviv, and West Jerusalem contributing $22.8 \%, 24.6 \%, 24.8 \%, 12.7 \%$, and $15.87 \%$ to the total $\mathrm{PM}_{2.5}$ mass, respectively. The contribution of carbonaceous material to total mass ranged from $16.7 \%$ to $64.3 \%$ at the eleven sites and dominated the $\mathrm{PM}_{2.5}$ profile in Zarka and Nablus. The differences are likely to be due to variable contributions of local combustion sources such as residential heating with solid fuels (coal, wood), vehicle exhaust, biogenic emissions, and photochemical reactions [75]. The inorganic ion fraction
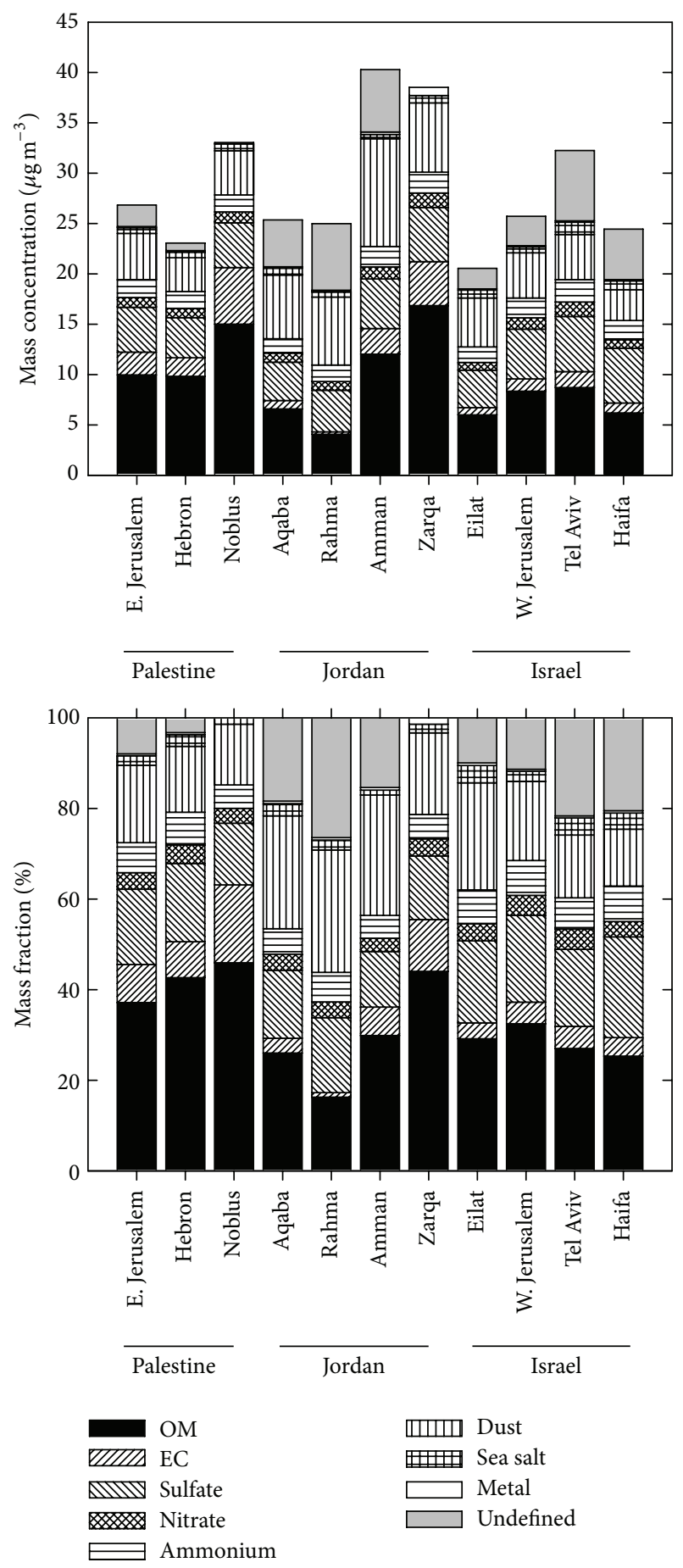

FIgURE 7: Annual average mass concentration (top) and mass fraction (bottom) of major $\mathrm{PM}_{2.5}$ chemical components for each site.

constituted $20.3 \%$ to $35.2 \%$ of the total $\mathrm{PM}_{2.5}$ mass and was the main contributor in Haifa and Eliat. Trace elements contributed only $0.83 \%$ to the $\mathrm{PM}_{25}$ at the eleven sites. The contribution of sea salt to the $\mathrm{PM}_{2.5}$ mass across the sites varied from 3.8\% in Tel Aviv and Haifa, close to the coast, to $1.1 \%$ in Amman, land inwards. This result indicates the variability and the gradient of sea spray emissions to $\mathrm{PM}_{2.5}$ from coastal to inland areas in the region. 
Similar conclusions representing observed $\mathrm{PM}_{2.5}$ mass closure problems due to unidentified chemical components are drawn by other studies [75, 76]. Several factors may be responsible for the discrepancies observed in mass closure. Estimates of the organic matter amounts and the crustal material components were simplified and contain high uncertainties. Organic matter estimates may have been probably underestimated by using 1.8 as the conversion factor at all study sites. Values as high as 2.1 have been widely used in the literature as the conversion factor [77, 78]. Large uncertainties are also associated with the contribution of crustal components. Estimation of minerals and trace elements included only the oxides, however, metals in dust may be in other forms $[76,79]$. Furthermore, unidentified water content in the $\mathrm{PM}_{2.5}$ samples may lead to the $\mathrm{PM}_{2.5}$ mass closure problems. Other possible causes for $\mathrm{PM}_{2.5}$ mass closure problem could be artifacts during sampling and systematic errors in chemical analysis.

\section{Conclusions}

For the first time ambient $\mathrm{PM}_{2.5}$ mass concentrations were monitored in three countries in the Middle East (Jordan, Palestinian Authority, and Israel) for 52 consecutive weeks. Mass concentrations, chemical compositions, seasonal variation, and site-to-site variations of the $\mathrm{PM}_{2.5}$ data were examined. The mass concentrations of $\mathrm{PM}_{2.5}$ across the 11 sites varied from 20.1 to $40.3 \mu \mathrm{g} / \mathrm{m}^{3}$, with an average of $28.5 \mu \mathrm{g} / \mathrm{m}^{3}$. $\mathrm{PM}_{2.5}$ mass concentrations exhibited strong monthly variation across 11 sites, with the maximum difference occurring in May and November. Average OC and EC concentrations were $5.30 \pm 4.03$ and $2.06 \pm 8.93 \mu \mathrm{g} / \mathrm{m}^{3}$, respectively, and the average OC ratio was $2.57 \pm 2.08$. The study also revealed that heavy metals in $\mathrm{PM}_{2.5}$ varied significantly across the sites. Sulfate and nitrate are by far the most prominent anions and ammonium is the prominent cation in the $\mathrm{PM}_{2.5}$ fraction at all sites.

Obvious seasonal variations of $\mathrm{PM}_{2.5}$ mass concentrations were observed. $\mathrm{PM}_{2.5}$ concentrations were highest during the Q2 and tended to be at their lowest concentrations during the Q4. In particular, ambient $\mathrm{PM}_{2.5}$ levels in AprilMay were clearly impacted by dust storms.

Overall, carbonaceous aerosol was the most abundant species and averaged $40 \%$ of the $\mathrm{PM}_{2.5}$ mass, while crustal matter and ionic species, namely, sulfate, nitrate, and ammonium, were also major components. Measured species accounted for $87 \%$ of the observed mass. Additional work is needed to improve the mass balance and to obtain the source profiles needed to use this data for source apportionment.

\section{Conflict of Interests}

The authors declare that they have no conflict of interests regarding the publication of this paper.

\section{Acknowledgments}

Present research was developed in the framework of the Middle East Consortium for Aerosol Research Study (MECARS), funded by the MERC Grant Award no. M23-020. We are also greatly appreciative of all staff for their support in field sampling and project management. We acknowledge Chris Worley, Maya Orf, and Jeff DeMinter for the assistance with the analysis of water-soluble ions by ion chromatography and assistance with quality control and quality assurance. We would also like to thank Judy Chow at DRI for conducting the XRF analysis, Yinon Rudich, Sveta Katman, and Mia Moonshine at the Weizmann Institute for conducting the ECOC analysis, and Professor Yigal Erel for providing laboratory space for the preparation and weighing of the filters.

\section{References}

[1] P. R. Buseck and S. E. Schwartz, "Tropospheric aerosols," in Treatise on Geochemistry, pp. 91-142, Elsevier, San Diego, Calif, USA, 2003.

[2] P. Forster, V. Ramaswamy, P. Artaxo et al., "Changes in atmospheric constituents and in radiative forcing," in Climate Change 2007: The Physical Science Basis: Contribution of Working Group I to the Fourth Assessment Report of the Intergovernmental Panel on Climate Change, pp. 129-234, Cambridge University Press, New York, NY, USA, 2007.

[3] L. Treut, R. Somerville, U. Cubasch et al., "Historical overview of climate change science," Earth, vol. 43, no. 1, pp. 93-127, 2007.

[4] F. Dominici, R. D. Peng, M. L. Bell et al., "Fine particulate air pollution and hospital admission for cardiovascular and respiratory diseases," Journal of the American Medical Association, vol. 295, no. 10, pp. 1127-1134, 2006.

[5] M. Franklin, P. Koutrakis, and J. Schwartz, "The role of particle composition on the association between $\mathrm{PM}_{2.5}$ and mortality," Epidemiology, vol. 19, no. 5, pp. 680-689, 2008.

[6] C. A. Pope III, M. J. Thun, M. M. Namboodiri et al., "Particulate air pollution as a predictor of mortality in a prospective study of US adults," The American Journal of Respiratory and Critical Care Medicine, vol. 151, no. 3, pp. 669-674, 1995.

[7] World Health Organization, Guidelines for Air Quality, World Health Organization, 2001.

[8] C. A. Pope III and D. W. Dockery, "Health effects of fine particulate air pollution: lines that connect," Journal of the Air and Waste Management Association, vol. 56, no. 6, pp. 709-742, 2006.

[9] A. A. Al-Hasaan, T. F. Dann, and P. F. Brunet, "Air pollution monitoring in Amman, Jordan," Journal of the Air and Waste Management Association, vol. 42, no. 6, pp. 814-816, 1992.

[10] D. K. Deshmukh, M. K. Deb, Y. I. Tsai, and S. L. Mkoma, "Water soluble ions in $\mathrm{PM}_{2.5}$ and $\mathrm{PM}_{1}$ aerosols in Durg city, Chhattisgarh, India," Aerosol and Air Quality Research, vol. 11, no. 6, pp. 696-708, 2011.

[11] D. K. Deshmukh, M. K. Deb, Y. I. Tsai, and S. L. Mkoma, "Atmospheric ionic species in $\mathrm{PM}_{2.5}$ and $\mathrm{PM}_{1}$ aerosols in the ambient air of eastern central India," Journal of Atmospheric Chemistry, vol. 66, no. 1-2, pp. 81-100, 2010.

[12] D. K. Deshmukh, Y. I. Tsai, M. K. Deb, and S. L. Mkoma, "Characterization of dicarboxylates and inorganic Ions in urban $\mathrm{PM}_{10}$ aerosols in the Eastern Central India," Aerosol and Air Quality Research, vol. 12, no. 4, pp. 592-607, 2012.

[13] M. A. Hassanien, J. Rieuwerts, A. A. Shakour, and A. Bittó, "Seasonal and annual variations in air concentrations of $\mathrm{Pb}, \mathrm{Cd}$ and PAHs in Cairo, Egypt," International Journal of Environmental Health Research, vol. 11, no. 1, pp. 13-27, 2001. 
[14] H. Kouyoumdjian and N. A. Saliba, "Mass concentration and ion composition of coarse and fine particles in an urban area in Beirut: effect of calcium carbonate on the absorption of nitric and sulfuric acids and the depletion of chloride," Atmospheric Chemistry and Physics, vol. 6, no. 7, pp. 1865-1877, 2006.

[15] A. Wanger, M. Peleg, G. Sharf et al., "Some observational and modeling evidence of long-range transport of air pollutants from Europe toward the Israeli coast," Journal of Geophysical Research, vol. 105, no. D6, pp. 7177-7186, 2000.

[16] B. Graham, A. H. Falkovich, Y. Rudich, W. Maenhaut, P. Guyon, and M. O. Andreae, "Local and regional contributions to the atmospheric aerosol over Tel Aviv, Israel: a case study using elemental, ionic and organic tracers," Atmospheric Environment, vol. 38, no. 11, pp. 1593-1604, 2004.

[17] V. Matvev, U. Dayan, I. Tass, and M. Peleg, "Atmospheric sulfur flux rates to and from Israel," Science of the Total Environment, vol. 291, no. 1-3, pp. 143-154, 2002.

[18] A. Zanobetti, M. Franklin, P. Koutrakis, and J. Schwartz, "Fine particulate air pollution and its components in association with cause-specific emergency admissions," Environmental Health, vol. 8, no. 1, article 58, 2009.

[19] J. A. Sarnat, T. Moise, J. Shpund et al., "Assessing the spatial and temporal variability of fine particulate matter components in Israeli, Jordanian, and Palestinian cities," Atmospheric Environment, vol. 44, no. 20, pp. 2383-2392, 2010.

[20] US EPA, Quality Assurance Guidance Document-Method Compendium: Field Standard Operating Procedures for the $P M_{2.5}$ Performance Evaluation Program, US EPA, Triangle Park, NC, USA, 2006

[21] E. von Schneidemesser, J. Zhou, E. A. Stone et al., "Seasonal and spatial trends in the sources of fine particle organic carbon in Israel, Jordan, and Palestine," Atmospheric Environment, vol. 44, no. 30, pp. 3669-3678, 2010.

[22] J. J. Schauer, B. T. Mader, J. T. Deminter et al., "ACE-Asia intercomparison of a thermal-optical method for the determination of particle-phase organic and elemental carbon," Environmental Science and Technology, vol. 37, no. 5, pp. 993-1001, 2003.

[23] S. C. Kerr, J. J. Schauer, and B. Rodger, "Regional haze in Wisconsin: sources and the spatial distribution," Journal of Environmental Engineering and Science, vol. 3, no. 3, pp. 213222, 2004.

[24] R. Kellog and W. J. Winberry, EPA Compendium Method 10-3.3: Determination of Metals in Ambient Particulate Matter Using XRay Fluorescence (XRF) Spectroscopy, US EPA, Washington, DC, USA, 1999.

[25] J. P. Miller-Schulze, M. M. Shafer, J. J. Schauer et al., "Characteristics of fine particle carbonaceous aerosol at two remote sites in Central Asia," Atmospheric Environment, vol. 45, no. 38, pp. 6955-6964, 2011.

[26] E. A. Stone, S.-C. Yoon, and J. J. Schauer, "Chemical characterization of fine and coarse particles in Gosan, Korea during springtime dust events," Aerosol and Air Quality Research, vol. 11, no. 1, pp. 31-43, 2011.

[27] U. Dayan, Y. Erel, J. Shpund, L. Kordova, A. Wanger, and J. J. Schauer, "The impact of local sources and meteorological factors on nitrogen oxide and particulate matter concentrations: a case study of the day of atonement in Israel," Atmospheric Environment, vol. 45, no. 19, pp. 3325-3332, 2011.

[28] H. S. Lee and B.-W. Kang, "Chemical characteristics of principal $\mathrm{PM}_{2.5}$ species in Chongju, South Korea," Atmospheric Environment, vol. 35, no. 4, pp. 739-746, 2001.
[29] J. J. Lin and H.-S. Tai, "Concentrations and distributions of carbonaceous species in ambient particles in Kaohsiung City, Taiwan," Atmospheric Environment, vol. 35, no. 15, pp. 26272636, 2001.

[30] S. S. Park and Y. J. Kim, " $\mathrm{PM}_{2.5}$ particles and size-segregated ionic species measured during fall season in three urban sites in Korea," Atmospheric Environment, vol. 38, no. 10, pp. 1459-1471, 2004.

[31] S. S. Park, Y. J. Kim, and K. Fung, "Characteristics of $\mathrm{PM}_{2.5}$ carbonaceous aerosol in the Sihwa industrial area, Korea," Atmospheric Environment, vol. 35, no. 4, pp. 657-665, 2001.

[32] X. Yao, A. P. S. Lau, M. Fang, C. K. Chan, and M. Hu, "Size distributions and formation of ionic species in atmospheric particulate pollutants in Beijing, China: 1-inorganic ions," Atmospheric Environment, vol. 37, no. 21, pp. 2991-3000, 2003.

[33] B. Ye, X. Ji, H. Yang et al., "Concentration and chemical composition of $\mathrm{PM}_{2.5}$ in Shanghai for a 1-year period," Atmospheric Environment, vol. 37, no. 4, pp. 499-510, 2003.

[34] J. P. Pinto, A. S. Lefohn, and D. S. Shadwick, "Spatial variability of $\mathrm{PM}_{2.5}$ in urban areas in the United States," Journal of the Air and Waste Management Association, vol. 54, no. 4, pp. 440-449, 2004.

[35] X. Querol, A. Alastuey, C. R. Ruiz et al., "Speciation and origin of $\mathrm{PM}_{10}$ and $\mathrm{PM}_{2.5}$ in selected European cities," Atmospheric Environment, vol. 38, no. 38, pp. 6547-6555, 2004.

[36] W. C. Malm, B. A. Schichtel, M. L. Pitchford, L. L. Ashbaugh, and R. A. Eldred, "Spatial and monthly trends in speciated fine particle concentration in the United States," Journal of Geophysical Research, vol. 109, no. D3, Article ID D03306, 2004.

[37] K. He, F. Yang, Y. Ma et al., "The characteristics of $\mathrm{PM}_{2.5}$ in Beijing, China," Atmospheric Environment, vol. 35, no. 29, pp. 4959-4970, 2001.

[38] J.-P. Putaud, R. van Dingenen, A. Alastuey et al., "A European aerosol phenomenology-3: physical and chemical characteristics of particulate matter from 60 rural, urban, and kerbside sites across Europe," Atmospheric Environment, vol. 44, no. 10, pp. 1308-1320, 2010.

[39] N. S. Duzgoren-Aydin and A. Aydin, "Chemical and mineralogical heterogeneities of weathered igneous profiles: implications for landslide investigations," Natural Hazards and Earth System Science, vol. 6, no. 2, pp. 315-322, 2006.

[40] E. Coz, F. J. Gómez-Moreno, G. S. Casuccio, and B. Artínano, "Variations on morphology and elemental composition of mineral dust particles from local, regional, and long-range transport meteorological scenarios," Journal of Geophysical Research, vol. 115, no. D12, Article ID D12204, 2010.

[41] E. Vega, V. Mugica, E. Reyes, G. Sánchez, J. C. Chow, and J. G. Watson, "Chemical composition of fugitive dust emitters in Mexico city," Atmospheric Environment, vol. 35, no. 23, pp. 4033-4039, 2001.

[42] J. H. Lee and P. K. Hopke, "Apportioning sources of $\mathrm{PM}_{2.5}$ in St. Louis, MO using speciation trends network data," Atmospheric Environment, vol. 40, no. 2, pp. 360-377, 2006.

[43] M. L. Bell, F. Dominici, K. Ebisu, S. L. Zeger, and J. M. Samet, "Spatial and temporal variation in $\mathrm{PM}_{2.5}$ chemical composition in the United States for health effects studies," Environmental Health Perspectives, vol. 115, no. 7, pp. 989-995, 2007.

[44] J. L. Feng, Z. G. Guo, T. R. Zhang, X. H. Yao, C. K. Chan, and M. Fang, "Source and formation of secondary particulate matter in $\mathrm{PM}_{2.5}$ in Asian continental outflow," Journal of Geophysical Research, vol. 117, no. D3, Article ID D03302, 2012. 
[45] J.-B. Heo, P. K. Hopke, and S.-M. Yi, "Source apportionment of $\mathrm{PM}_{2.5}$ in seoul, korea," Atmospheric Chemistry and Physics, vol. 9, no. 14, pp. 4957-4971, 2009.

[46] K. Ito, N. Xue, and G. Thurston, "Spatial variation of $\mathrm{PM}_{2.5}$ chemical species and source-apportioned mass concentrations in New York City," Atmospheric Environment, vol. 38, no. 31, pp. 5269-5282, 2004.

[47] G. Lonati, M. Giugliano, P. Butelli, L. Romele, and R. Tardivo, "Major chemical components of $\mathrm{PM}_{2.5}$ in Milan (Italy)," Atmospheric Environment, vol. 39, no. 10, pp. 1925-1934, 2005.

[48] R. Arimoto, R. A. Duce, D. L. Savoie et al., "Relationships among aerosol constituents from Asia and the North Pacific during PEM-West A," Journal of Geophysical Research, vol. 101, no. D1, pp. 2011-2023, 1996.

[49] B. J. Huebert, M. X. Wang, and W. X. Lü, "Atmospheric nitrate, sulfate, ammonium and calcium concentrations in China," Tellus B, vol. 40, no. 4, pp. 260-269, 1988.

[50] H.-Y. Xiao and C.-Q. Liu, "Chemical characteristics of watersoluble components in TSP over Guiyang, SW China, 2003," Atmospheric Environment, vol. 38, no. 37, pp. 6297-6306, 2004.

[51] Y. Wang, G. Zhuang, A. Tang et al., "The ion chemistry and the source of $\mathrm{PM}_{2.5}$ aerosol in Beijing," Atmospheric Environment, vol. 39, no. 21, pp. 3771-3784, 2005.

[52] T. Miyakawa, N. Takegawa, and Y. Kondo, "Removal of sulfur dioxide and formation of sulfate aerosol in Tokyo," Journal of Geophysical Research, vol. 112, no. D13, Article ID D13209, 2007.

[53] M. Biasioli, R. Barberis, and F. Ajmone-Marsan, "The influence of a large city on some soil properties and metals content," Science of the Total Environment, vol. 356, no. 1-3, pp. 154-164, 2006.

[54] A. A. Odewande and A. F. Abimbola, "Contamination indices and heavy metal concentrations in urban soil of Ibadan metropolis, southwestern Nigeria," Environmental Geochemistry and Health, vol. 30, no. 3, pp. 243-254, 2008.

[55] G. Shi, Z. Chen, S. Xu et al., "Potentially toxic metal contamination of urban soils and roadside dust in Shanghai, China," Environmental Pollution, vol. 156, no. 2, pp. 251-260, 2008.

[56] J. Han, M. Kamber, and A. K. H. Tung, "Spatial clustering methods in data mining: a survey," in Geographic Data Mining and Knowledge Discovery, vol. 21, p. 48, Taylor \& Francis, Boca Raton, Fla, USA, 2001.

[57] J. H. Lee, P. K. Hopke, and J. R. Turner, "Source identification of airborne $\mathrm{PM}_{2.5}$ at the St. Louis-Midwest supersite," Journal of Geophysical Research, vol. 111, no. D10, Article ID D10S10, 2006.

[58] S. Chellam, P. Kulkarni, and M. P. Fraser, "Emissions of organic compounds and trace metals in fine particulate matter from motor vehicles: a tunnel study in Houston, Texas," Journal of the Air and Waste Management Association, vol. 55, no. 1, pp. 60-72, 2005.

[59] R. M. Harrison, J. Yin, D. Mark et al., "Studies of the coarse particle $(2.5-10 \mu \mathrm{m})$ component in UK urban atmospheres," Atmospheric Environment, vol. 35, no. 21, pp. 3667-3679, 2001.

[60] R. Vecchi, G. Marcazzan, and G. Valli, "A study on nighttimedaytime $\mathrm{PM}_{10}$ concentration and elemental composition in relation to atmospheric dispersion in the urban area of Milan (Italy)," Atmospheric Environment, vol. 41, no. 10, pp. 2136-2144, 2007.

[61] J. J. Cao, S. C. Lee, K. F. Ho et al., "Characteristics of carbonaceous aerosol in Pearl River Delta region, China during 2001 winter period," Atmospheric Environment, vol. 37, no. 11, pp. 1451-1460, 2003.
[62] J. C. Chow, J. G. Watson, E. M. Fujita, Z. Lu, D. R. Lawson, and L. L. Ashbaugh, "Temporal and spatial variations of $\mathrm{PM}_{2.5}$ and $\mathrm{PM}_{10}$ aerosol in the Southern California air quality study," Atmospheric Environment, vol. 28, no. 12, pp. 2061-2080, 1994.

[63] K. Funasaka, T. Miyazaki, T. Kawaraya, K. Tsuruho, and T. Mizuno, "Characteristics of particulates and gaseous pollutants in a highway tunnel," Environmental Pollution, vol. 102, no. 2-3, pp. 171-176, 1998.

[64] B. J. Turpin and H.-J. Lim, "Species contributions to $\mathrm{PM}_{2.5}$ mass concentrations: revisiting common assumptions for estimating organic mass," Aerosol Science and Technology, vol. 35, no. 1, pp. 602-610, 2001.

[65] B. J. Turpin, P. Saxena, and E. Andrews, "Measuring and simulating particulate organics in the atmosphere: problems and prospects," Atmospheric Environment, vol. 34, no. 18, pp. 2983-3013, 2000.

[66] J. Viidanoja, M. Sillanpää, J. Laakia et al., "Organic and black carbon in $\mathrm{PM}_{2.5}$ and $\mathrm{PM}_{10}$ : 1 year of data from an urban site in Helsinki, Finland," Atmospheric Environment, vol. 36, no. 19, pp. 3183-3193, 2002.

[67] Y. P. Kim, K.-C. Moon, J. H. Lee, and N. J. Baik, "Concentrations of carbonaceous species in particles at Seoul and Cheju in Korea," Atmospheric Environment, vol. 33, no. 17, pp. 2751-2758, 1999.

[68] B. J. Turpin and J. J. Huntzicker, "Secondary formation of organic aerosol in the Los Angeles Basin: a descriptive analysis of organic and elemental carbon concentrations," Atmospheric Environment A: General Topics, vol. 25, no. 2, pp. 207-215, 1991.

[69] B. J. Turpin and J. J. Huntzicker, "Identification of secondary organic aerosol episodes and quantitation of primary and secondary organic aerosol concentrations during SCAQS," Atmospheric Environment, vol. 29, no. 23, pp. 3527-3544, 1995.

[70] J. J. Cao, S. C. Lee, J. C. Chow et al., "Spatial and seasonal distributions of carbonaceous aerosols over China," Journal of Geophysical Research, vol. 112, no. D22, Article ID D22S11, 2007.

[71] Y. M. Han, Z. W. Han, J. J. Cao et al., "Distribution and origin of carbonaceous aerosol over a rural high-mountain lake area, Northern China and its transport significance," Atmospheric Environment, vol. 42, no. 10, pp. 2405-2414, 2008.

[72] L. M. Castro, C. A. Pio, R. M. Harrison, and D. J. T. Smith, "Carbonaceous aerosol in urban and rural European atmospheres: estimation of secondary organic carbon concentrations," Atmospheric Environment, vol. 33, no. 17, pp. 2771-2781, 1999.

[73] P. Riley and R. Chester, Introduction to Marine Chemistry, Academic Press, London, UK, 1971.

[74] J.-P. Putaud, F. Raes, R. van Dingenen et al., "A European aerosol phenomenology-2: chemical characteristics of particulate matter at kerbside, urban, rural and background sites in Europe," Atmospheric Environment, vol. 38, no. 16, pp. 25792595, 2004.

[75] M. Sillanpää, R. Hillamo, S. Saarikoski et al., "Chemical composition and mass closure of particulate matter at six urban sites in Europe," Atmospheric Environment, vol. 40, no. 2, pp. 212-223, 2006.

[76] S. M. Almeida, C. A. Pio, M. C. Freitas, M. A. Reis, and M. A. Trancoso, "Approaching $\mathrm{PM}_{2.5}$ and $\mathrm{PM}_{2.5-10}$ source apportionment by mass balance analysis, principal component analysis and particle size distribution," Science of the Total Environment, vol. 368, no. 2-3, pp. 663-674, 2006.

[77] T. Gnauk, E. Brüggemann, K. Müller et al., "Aerosol characterisation at the FEBUKO upwind station Goldlauter (I): particle 
mass, main ionic components, OCEC, and mass closure," Atmospheric Environment, vol. 39, no. 23-24, pp. 4209-4218, 2005.

[78] A. Plewka, T. Gnauk, E. Brüggemann, and H. Herrmann, "Biogenic contributions to the chemical composition of airborne particles in a coniferous forest in Germany," Atmospheric Environment, vol. 40, pp. 103-115, 2006.

[79] S. L. Rees, A. L. Robinson, A. Khlystov, C. O. Stanier, and S. N. Pandis, "Mass balance closure and the federal reference method for $\mathrm{PM}_{2.5}$ in Pittsburgh, Pennsylvania," Atmospheric Environment, vol. 38, no. 20, pp. 3305-3318, 2004. 

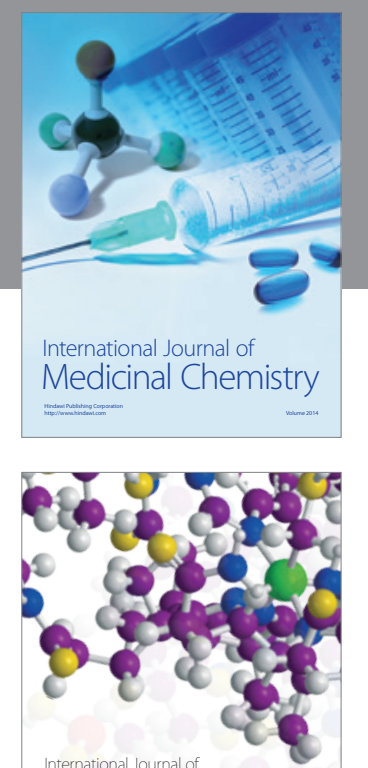

\section{Carbohydrate} Chemistry

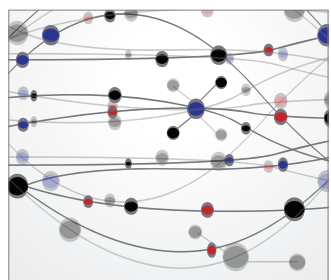

The Scientific World Journal

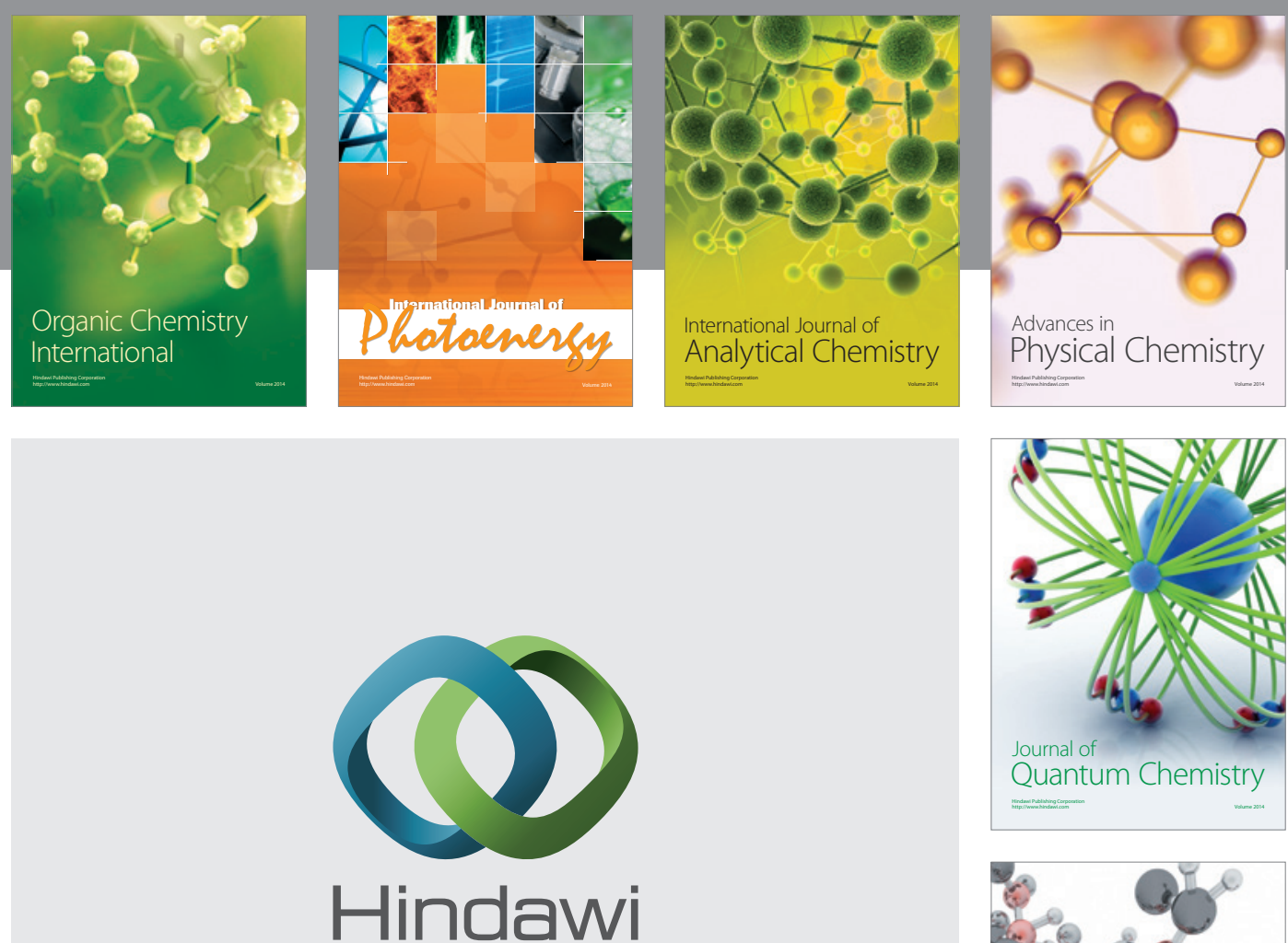

Submit your manuscripts at

http://www.hindawi.com

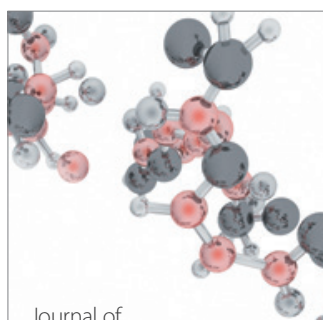

Analytical Methods

in Chemistry

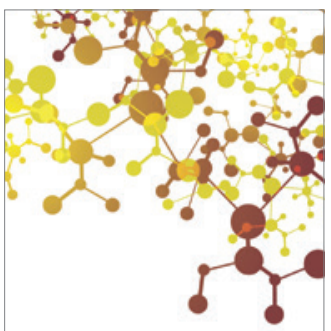

Journal of

Applied Chemistry



Inorganic Chemistry
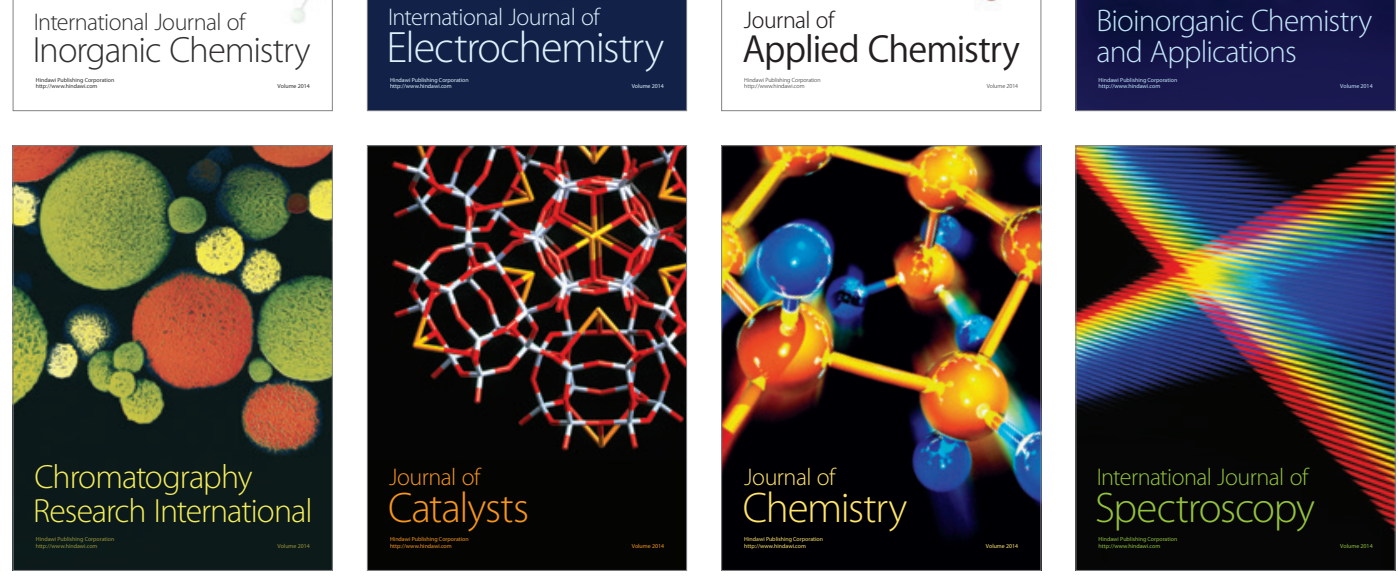